University of Tennessee Law

Legal Scholarship Repository: A Service of the Joel A. Katz Library

UTK Law Faculty Publications

$9-2020$

(In)Formal Marriage Equality

Michael J. Higdon

Follow this and additional works at: https://ir.law.utk.edu/utklaw_facpubs

Part of the Law Commons 


\section{University of Tennessee College of Law}

From the SelectedWorks of Michael J Higdon

September, 2020

\section{(In)Formal Marriage Equality}

Michael J Higdon 


\section{T THE UNVERSTIY OF TENNESSEE \\ KNOXVILLE}

COLLEGE OF LAW
Legal Studies

Research Paper Series

\footnotetext{
Research Paper \#397

September 2020
}

\title{
(In)Formal Marriage Equality
}

\author{
Michael J. Higdon \\ Fordham Law Review (Forthcoming)
}

This paper may be downloaded without charge from the Social Science Research Network Electronic library at http://ssrn.com/abstract $=\mathbf{3 6 5 5 6 8 7}$

Learn more about the University of Tennessee College of Law: law.utk.edu 


\title{
(IN)FORMAL MARRIAGE EQUALITY
}

\author{
Michael J. Higdon*
}

\begin{abstract}
In 2015, same-sex couples throughout the United States obtained formal marriage equality. But is the prospective ability to obtain marriage licenses sufficient to achieve Obergefell's promise of equality? What about individuals whose same-sex relationship did not survive-either through death or dissolution - to see marriage equality become the law of the land? Or those who did ultimately wed but now have a marriage that appears to be artificially short when considering just how long the couple has actually been together in a marriage-like relationship? With marriage benefits conditioned not only on the fact of marriage but also the length of marriage, individuals in both categories continue to suffer harm as a result of the unconstitutional laws that prevented them from marrying at an earlier point in time. Although some states have attempted to remedy this problem by backdating same-sex marriages, the reality is that the availability of such relief varies by state and, even so, no state has yet to formulate a test to adequately protect the interests of those individuals. This Article is the first to propose a specific solution to these problems - a solution that requires states to formulate and adopt a new equitable remedy, referred to here as Equitable Marriage. Drawing upon existing equitable doctrines that states have already developed to extend formal family law benefits to those in informal family-like relationships, Equitable Marriage would treat same-sex relationships that pre-dated formal marriage equality as the equivalent of a legal marriage with all the attendant rights and obligations. In the case of same-sex couples who ultimately wed, Equitable Marriage would require that this time count as part of the formal marriage so as to extend all marital benefits conditioned on length of marriage. To succeed, claimants would need to establish that the couple would have wed during that time period but for the unconstitutional laws depriving them of that fundamental right. Understanding the complexity of such an approach, this Article offers guidance on how courts should implement and apply Equitable Marriage so as to achieve full marriage equality while, at the same time, resisting impermissible gender stereotypes and heterosexist notions of how marriage "should" look.
\end{abstract}

\footnotetext{
* Associate Dean for Faculty Development and Professor of Law, University of Tennessee College of Law. I am grateful to the University of Tennessee College of Law, particularly Deans Melanie Wilson and Doug Blaze, for providing generous financial support for this project.
} 
TABLE OF CONTENTS

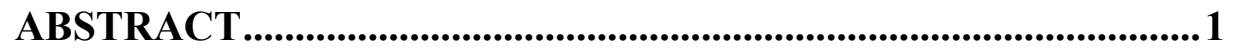

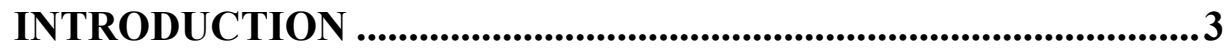

I. THE PATH TO FORMAL MARRIAGE EQUALITY .................. 7

II. OBERGEFELL AND PRE-EQUALITY “MARRIAGES" .......17

A. BENEFITS CONDITIONED ON LENGTH OF MARRIAGE..................... 18

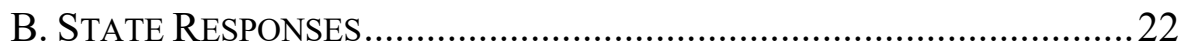

III. THE LAW OF INFORMAL FAMILY CREATION ................28

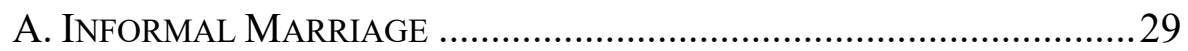

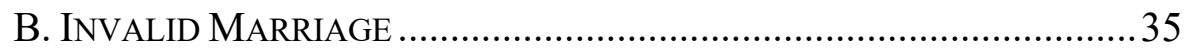

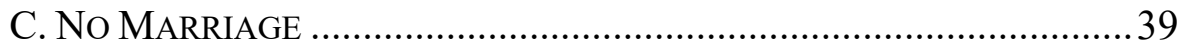

D. INFORMAL ADOPTION ........................................................ 42

E. No AdOPTION AND No BiOLOGICAL LiNK ....................................45

IV. EQUITABLE MARRIAGE .................................................48

A. FILling THE EQUitable Void...............................................50

B. APPLying EQUitable MARRIAGE ........................................55

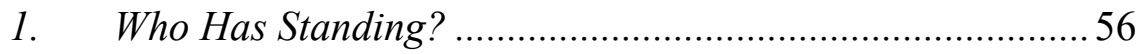

2. How Would a Claimant Prove an Equitable Marriage? .....58 CONCLUSION ......................................................................65 
"I made sure to add 'and days past' in our vows because by the time we got married, we had already lived together for 42 years. You can't forget that" ${ }^{1}$-Edith Windsor, named plaintiff in U.S. v. Windsor

\section{INTRODUCTION}

On three separate occasions, the United States has witnessed large, discrete groups of adults simultaneously earning the right to marry the person of their choice - a right that had been denied them for many years. The first occurred after passage of the Thirteenth Amendment, which cleared the way for former slaves to finally enter into legal marriages. ${ }^{2}$ The second came in 1967 after the Supreme Court's decision in Loving v. Virginia struck down anti-miscegenation laws in the sixteen states that still prohibited interracial marriage. ${ }^{3}$ The third example, which forms the basis of this Article, came in 2015 when the Supreme Court's ruling in Obergefell v. Hodges ushered in marriage equality for same-sex couples throughout the United States. ${ }^{4}$ In each instance, those couples impacted by the change in law were now permitted to solemnize their relationships and, thus, enjoy all the legal protections that flow from formal marriage. At the same time, each prompted the question of what, if any, legal effect was to be given those couples that spent time in a quasi-marital state while awaiting the right to legally wed. After all, to ignore those years altogether would lead to a number of legal harms-harms inconsistent with the ideal of true marriage equality. ${ }^{5}$

To illustrate, consider Michael Ely and James Taylor, who met in 1971 when Michael was eighteen and James was twenty. ${ }^{6}$ The two men became involved and would spend the next forty-three years together, living first in California and later in Arizona. In October 2014, five days after U.S. District

\footnotetext{
${ }^{1}$ Corinne Werder, 20 Epic Edie Windsor Quotes To Always Remember Her By, Go Magazine (Sept. 13, 2017): https://medium.com/@lesbiantech/11-quotes-from-our-heroedie-windsor-at-lesbians-who-tech-new-york-4d7d0e8c9f6b

2 Prior to emancipation, slaves were permitted to "marry," but such unions had absolutely no legal effect: "As chattel, slaves were objects, not subjects. Marriage for them was not an inviolable union between two people, but an institution defined and controlled by the superior relationship of slave to master." TERA W. HUNTER, BOUND IN WEDLOCK: SLAVE And Free Black Marriage in The NineteEnth CENTURy 6 (2017)

${ }^{3} 388$ U.S. 1 (1967); see Carlos A. Ball, The Blurring of the Lines: Children and Bans on Interracial Unions and Same-Sex Marriages, 76 FordHAM L. REV. 2733, 2746 (2008) ("Despite the moral and practical untenability of antimiscegenation laws, they remained in place in sixteen states (all of them in the South) by the time the Supreme Court decided Loving v. Virginia.").

${ }^{4} 135$ S. Ct. 2584 (2015).

${ }^{5}$ See infra Part II.A.

${ }^{6}$ The details of this case are all taken from the complaint filed on their behalf by Lambda Legal. See https://www.lambdalegal.org/in-court/legal-docs/ely_az_20181120_complaint.
} 
Court Judge John Sedgwick ruled that Arizona's prohibition on same-sex marriage was unconstitutional, ${ }^{7}$ the two men obtained a marriage license and married just two weeks later. Sadly, their legal marriage would only last six months because, in May of 2015, James died of cancer at the age of sixtythree. Michael, devastated by the loss of his partner of over forty years, also suffered financially given that the couple primarily relied on James's employment for income. Michael filed for Social Security benefits as James's surviving spouse, but his application was denied because of a provision in the Social Security Act that requires a surviving spouse to have been married to the "insured individual" for nine months in order to qualify for benefits. ${ }^{8}$ Owing to the timing of James' death-but primarily to the fact the two men had been legally prohibited from getting married for the majority of their relationship-Michael was three months shy of meeting that requirement.

Ely and Taylor represent but one of the many same-sex couples whose relationships began long before marriage equality was even a consideration, much less a reality. For those couples that were ultimately able to wed, their marriage licenses bestowed legal benefits that had been denied them for many years. For instance, James Obergefell, the named plaintiff in the case responsible for securing this new freedom, had been living in a marriage-like relationship with his partner for twenty-two years. ${ }^{9}$ Similarly, Edith Windsor, the woman responsible for ending that portion of the Defense of Marriage Act that excluded same-sex spouses from the federal definition of "spouse," 10 had been with her partner forty years before the two were finally permitted to marry. ${ }^{11}$ Other same-sex couples never even got that opportunity as, in many cases, individuals died before they could legally marry the person they had been waiting to wed. The question that emerges then is what remedy should apply to those in same-sex relationships who were either never permitted to wed or those whose eventual marriage fails to capture the true length of their relationship.

In Obergefell, Justice Kennedy spoke of the "constellation of benefits"12 that marriage affords, and two years later, the Court reiterated that "a State may not exclude same-sex couples from civil marriage on the same terms and

\footnotetext{
${ }^{7}$ See Connolly v. Jeanes, 73 F. Supp. 3d 1094 (D. Ariz. 2014)

${ }^{8}$ See 42 U.S.C. $\S \S 402(\mathrm{e}),(\mathrm{f}), 416(\mathrm{c}),(\mathrm{g})$.

9 Tom Watts, From Windsor to Obergefell: The Struggle for Marriage Equality Continued, 9 HARV. L. \& POL'Y REV. S52, S60 (2015).

${ }^{10}$ See United States v. Windsor, 570 U.S. 744 (2013).

${ }^{11}$ Edith Windsor and her partner, Thea Spyer, were wed in 2007 in Canada. See id. at 749. See also Christine L. Nemacheck, The Path to Obergefell: Saying "I Do" to New Judicial Federalism?, 54 WASH. U. J.L. \& POL'Y 149, 163 (2017) (noting that, prior to marrying, the couple had been together for over forty years).

12135 S. Ct. at 2601.
} 
conditions as opposite-sex couples." 13 As the example that began this Article illustrates, however, a number of marital benefits are tied not just to the fact of marriage, but to the length of the marriage. ${ }^{14}$ Accordingly, if states are to comply with Obergefell's directive, there must be some accounting for the time same-sex couples spent in relationships that-but for the legal prohibitions against it - would have been marriages. And this requirement must apply to those who were precluded from ever marrying as well as those same-sex spouses who first spent time in a quasi-marital state awaiting that right. To do otherwise would permit an unconstitutional law-the kind Justice Scalia has described as "void, and is as no law"15 - to continue to harm the very population on whose behalf the law was struck down. Such a result is impermissible. As the Supreme Court has made clear, when a law is deemed unconstitutional, "that rule is the controlling interpretation of federal law and must be given full retroactive effect in all cases still open on direct review and as to all events, regardless of whether such events predate or postdate our announcement of the rule." 16

Whereas other scholars have noted this need for some form of retroactive application of Obergefell, ${ }^{17}$ there is as of yet no formulation of how exactly courts should do that. And to the extent courts have wrestled with this issue, they have taken vastly different approaches and have arrived at opposite conclusions. ${ }^{18} \mathrm{~A}$ few have given effect to the time same-sex couples spent in relationships while awaiting the right to formally wed, doing so either through laws relating to common law marriage or by looking into whether the couple would have married earlier had that option been available to them. ${ }^{19}$ Others have simply refused to go beyond the dates of a legal marriage, thus refusing to grant any legal significance to time spent in a pre-equality relationship, regardless of how long that relationship lasted or the severity of the harms that would result from failing to count that time. ${ }^{20}$ Thus, true marriage equality remains a work in progress, which is problematic not only for the continued discrimination faced by those who - pre-Obergefell—spent

${ }^{13}$ Pavan v. Smith, 137 S.Ct. 2075, 2078 (2017).

${ }^{14}$ See infra Part II.A.

${ }^{15}$ Reynoldsville Casket Co. v. Hyde, 514 U.S. 749, 760 (Scalia, J., dissenting) (1995) (quoting Ex parte Siebold, 100 U.S. 371, 376 (1879)).

${ }^{16}$ Harper v. Virginia Dep't of Taxation, 509 U.S. 86, 97 (1993) (emphasis added).

${ }^{17}$ See, e.g., Peter Nicolas, Backdating Marriage, 105 CALIF. L. REV. 395 (2017); Charles W. Rhodes, Loving Retroactivity, 45 FLA. S. L. REV. 383 (2018); Mark Strasser, Obergefell, Retroactivity, and Common Law Marriage, 9 NE. U.L. ReV. 379 (2017); Lee-Ford Tritt, Moving Forward by Looking Back: The Retroactive Application of Obergefell, 2016 WisC. L. REV. 873.

${ }^{18}$ See infra Part II.B.

${ }^{19} \mathrm{Id}$.

${ }^{20}$ See infra notes 163-171 and accompanying text. 
time in committed, same-sex relationships, but the fact that the right to marry is a constitutionally protected right and, as such, some standards are required. After all, "it is the nature of a constitution to set outer limits to legislative competence." 21

There are, however, a number of thorny questions associated with any attempt to backdate same-sex marriages. For instance, how does the law determine when a premarital relationship became sufficiently "marriagelike" to warrant counting some portion of it toward the length of the eventual marriage? Relatedly, how can the law accurately determine when a same-sex couple would have married had they been given the opportunity? Further, given the discrimination faced by the LGBTQ community, many of them might have kept their relationships secret, making it difficult for them to now prove the earlier existence of a "marriage-like" relationship. Finally, given the heteronormative foundation of marriage, ${ }^{22}$ what does "marriage-like" even mean anymore, especially when applied to a group of Americans whom society has for decades conditioned to view marriage as a social institution reserved for people who are unlike them. ${ }^{23}$ As one commentator said after witnessing marriage equality in the Netherlands in 1998: "[I]t was an amazing feeling . . . because I had never imagined that possibility." 24

It is the goal of this Article to provide answers to those questions. In so doing, this Article seeks to offer a path forward for the states as they attempt to give effect to the full promise of Obergefell. That path is made easier by the fact that states already employ their inherent equitable powers to bestow family law protections upon informal relationships that arose outside the legal requirements for family formation. ${ }^{25}$ Although none provide an adequate remedy in this context, they are nonetheless instructive when it comes to fashioning a new equitable doctrine that would adequately address the time same-sex couples spent in marriage-like relationships while awaiting marriage equality. Essentially, that doctrine-referred to here as Equitable Marriage - would treat that time as either a legal marriage or, in the case of same-sex couples who ultimately wed, as part of the formal marriage if the

${ }^{21}$ Marc A. Franklin, The Origins and Constitutionality of Limitations on Truth as a Defense in Tort Law, 16 STAN. L. REV. 789, 798 (1964).

${ }^{22}$ Marc Spindelman, Homosexuality's Horizon, 54 EMORY L.J. 1361, 1371 (2005)

(referencing "[m]arriage's heteronormative roots").

${ }^{23}$ See Yuvraj Joshi, Respectable Queerness, 43 Colum. Hum. RTs. L. Rev. 415, 444 (2012) ("[I]t appears implausible that the law, once it has recognized same-sex marriage, will develop a more nuanced understanding of sexuality that undercuts its heteronormative assumptions.").

${ }^{24}$ Laura J. Kendall, Dancing with My Grandma: Talking with Robyn Ochs About Complex Identities and Simple Messages in the Marriage Equality Movement, in BiseXuality AND SAme-SeX Marriage 181, 199 (M. Paz Galupo ed., 2008).

${ }^{25}$ See infra Part III. 
claimant could establish that the couple would have wed during that time period but for the unconstitutional laws depriving them of that fundamental right.

This Article proceeds in four parts. Part I chronicles the history of formal marriage equality in the United States as it applies to same-sex couples. Part II then turns to informal marriage equality, focusing on how Obergefell stands for the proposition that, going forward, states must do more than simply issue marriage licenses in order to remedy the unconstitutional denial of same-sex couple's right to marry. In so doing, Part II explores the marital benefits tied to marriage, particularly those tied to length of marriage, and how states have attempted to answer the question of whether Obergefell demands retroactive application. Part III proposes the need for an equitable remedy that, in some form or another, all states must adopt. To understand that need and what form the remedy might take, Part III details similar equitable remedies that courts have previously relied upon in order to provide family law benefits to family-like relationships. Part IV then explores how the proposed remedy-referred to here as Equitable Marriage-would provide similar protections to those marriages that fail to account for informal relationships that would have been marriages had legal prohibitions not prevented solemnization. As part of that proposal, Part IV examines how courts might apply Equitable Marriage, offering potential solutions to the complications and objections any such remedy will inevitably bring.

\section{THE PATH TO FoRMAL MARRIAGE EQUALITY}

In 1967, when the Supreme Court struck down state laws that prohibited individuals from marrying someone of another race, the Court identified "freedom of choice" as an implicit component of the right to marry. ${ }^{26}$ That case was, of course, Loving v. Virginia, and five years later, Richard Baker and James McConnell would rely on it when they became the first same-sex couple to challenge discriminatory marriage laws. ${ }^{27}$ The two men had sought a marriage license under Minnesota law, which did not explicitly require the two parties to be of the opposite sex. ${ }^{28}$ Nonetheless, their application was

\footnotetext{
${ }^{26}$ Loving v. Virginia, 388 U.S. 1, 12 (1967) (“The Fourteenth Amendment requires that the freedom of choice to marry not be restricted by invidious racial discriminations.").

${ }^{27}$ Anthony Michael Kreis, Stages of Constitutional Grief: Democratic Constitutionalism and the Marriage Revolution, 20 U. PA. J. Const. L. 871, 881 (2018) ("Baker and McConnell alleged Minnesota's marriage law ran afoul of the First, Eighth, Ninth, and Fourteenth Amendments.").

${ }^{28}$ See Baker v. Nelson, 191 N.W.2d 185, 185 (1971) ("Petitioners contend, first, that the absence of an express statutory prohibition against same-sex marriages evinces a legislative intent to authorize such marriages.").
} 
denied, and the two men subsequently brought suit, arguing that "the right to marry without regard to the sex of the parties is a fundamental right of all persons and that restricting marriage to only couples of the opposite sex is irrational and invidiously discriminatory. ${ }^{29}$

Baker and McConnell lost at both the trial court and on appeal to the state supreme court. ${ }^{30}$ In ruling, the Supreme Court of Minnesota rejected the plaintiffs' reliance on Loving, holding that "in commonsense and in a constitutional sense, there is a clear distinction between a marital restriction based merely upon race and one based upon the fundamental difference in sex." ${ }^{11}$ On appeal to the United States Supreme Court, the two men would lose once more, this time with a mere one-sentence summary disposition: "The appeal is dismissed for want of a substantial federal question." ${ }^{32}$ And with that, the nation's first legal challenge to state laws that prevented individuals from marrying a person of the same-sex would come to an end.

For the most part, the issue would lie dormant for the next twenty years. Then, in 1990, something happened that would cause the issue of same-sex marriage to "burst into the consciousness of the American public." 33 Specifically, three same-sex couples in Hawaii decided to apply for marriage licenses. ${ }^{34}$ When their applications were denied, the couples filed suit, arguing that Hawaii's marriage law, which "restrict[ed] the marital relation to a male and a female, ${ }^{35}$ was in violation of Hawaii's constitution. ${ }^{36}$ The trial court dismissed the case. ${ }^{37}$ On appeal to the Supreme Court of Hawaii, however, the court ruled that, although there was no fundamental right to

${ }^{29}$ Id. at 312 .

${ }^{30} \mathrm{Id}$.

${ }^{31} \mathrm{Id}$. at 315.

${ }^{32}$ Baker v. Nelson, 409 U.S. 810 (1972).

${ }_{33}$ Arthur S. Leonard, Going for the Brass Ring: The Case for Same-Sex Marriage 82 Cornell L. Rev. 572 (1997); see also Keith Cunningham-Parmeter, Marriage Equality, Workplace Inequality: The Next Gay Rights Battle, 67 FLA. L. REV. 1099, 1107 (2015) ([W]hen the Hawaii Supreme Court shocked the nation in 1993 and ruled in favor of Nina Baehr's petition to marry her female partner in Baehr v. Lewin, the issue of same-sex marriage drew prominent national attention."); David L. Chambers \& Nancy D. Polikoff, Family Law and Gay and Lesbian Family Issues in the Twentieth Century, 33 FAM. L.Q. 523, 526 (1999) (noting how the Hawaii opinion "stirred by far the most attention, for it led to the first appellate decision in the United States suggesting that same-sex couples were constitutionally entitled to marry and produced a seismic political reaction in Hawaii and the mainland").

${ }^{34}$ See Steven K. Homer, Against Marriage, 29 HARV. C.R.-C.L. L. REV. 505, 506 (1994)

("In December 1990, three same-sex couples-Ninia Baehr and Genora Dancel, Tammy Rodrigues and Antoinette Pregil, and Pat Lagon and Joseph Melilio-applied to Hawaii's Department of Health for marriage licenses.").

${ }^{35}$ Baehr v. Lewin, 852 P.2d 44, 60 (Haw. 1993)

${ }^{36} \mathrm{Id}$. at $49-50$.

${ }^{37} \mathrm{Id}$. at 52 . 
same-sex marriage, under the Hawaii Constitution "sex is a 'suspect category' for purposes of equal protection analysis." 38 For that reason, the court held that the state's discriminatory definition of marriage was presumptively unconstitutional, and the state could only rebut that presumption by a showing that "(a) the statute's sex-based classification is justified by compelling state interests and (b) the statute is narrowly drawn to avoid unnecessary abridgements of the applicant couples' constitutional rights." 39

On remand, Hawaii Circuit Judge Kevin S.C. Chang ruled that the state failed to rebut the presumption and issued an injunction that prevented the state from denying licenses solely because the applicants were of the same sex. ${ }^{40}$ Thus, in what was now 1996, Hawaii seemed poised to become the first state to recognize same-sex marriage. However, pending appeal, Judge Chang issued a stay of his order, and that appeal was subsequently mooted in 1998 when Hawaii voters passed a constitutional amendment, providing that "[t]he legislature shall have the power to reserve marriage to opposite-sex couples." 41 Americans did not know it at the time, but it would be another eight years before a state would legalize same-sex marriage, and it would not be Hawaii. ${ }^{42}$

Nonetheless, the fact that Hawaii had even considered legalizing samesex marriage caused great consternation among many of the other states, and the response was swift. ${ }^{43}$ With the assumption that same-sex marriages performed in one state would potentially be entitled to full faith and credit in all others, ${ }^{44}$ many states took what they hoped would be preemptive action and began the process of amending their constitutions to define marriage as being between one man and one woman. ${ }^{45}$ The hope was that, in so doing,

${ }^{38} I d$. at 67.

${ }^{39} \mathrm{Id}$.

${ }^{40}$ Baehr v. Miike, No. CIV. 91-1394, 1996 WL 694235 (Haw. Cir. Ct. Dec. 3, 1996).

${ }^{41}$ Haw. Const. art. I, $\$ 23$

${ }^{42}$ See infra notes 66-70 and accompanying text.

43 See Jane S. Schacter, Courts and the Politics of Backlash: Marriage Equality Litigation, Then and Now, 82 S. CAL. L. REV. 1153, 1157 (2009) (noting how events in Hawaii "ignited the national backlash against same-sex marriage).

${ }^{44}$ See Brian H. Bix, State Interest and Marriage-the Theoretical Perspective, 32 Hofstra L. REV. 93, 105-06 (2003) ("[T]he combination of national citizenship (as enforced by the Full Faith and Credit Clause) and the usual rules of recognizing marriages validly celebrated in another state, meant that . . . there was a fear . . that all other states would have to recognize same-sex unions celebrated in Hawaii.").

${ }^{45}$ See William Buss \& Emily Buss, Escaping the American Blot? A Comparative Look at Federalism in Australia and the United States Through the Lens of Family Law, 48 CORNELL INT'L L.J. 105, 133 n.151 (2015) ("Within twelve years of the Hawaii Supreme Court's ruling, many states, including Hawaii, had added an express ban on same-sex marriage to their laws, and a majority of these prohibitions were ultimately adopted as 
the state could refuse to recognize "marriages" that did not comply. Eventually, thirty-one states passed such amendments. ${ }^{46}$ Alabama, for example, passed the "Alabama Sanctity of Marriage Amendment," which provided that "[t]he State of Alabama shall not recognize as valid any marriage of parties of the same sex that occurred or was alleged to have occurred as a result of the law of any jurisdiction regardless of whether a marriage license was issued." ${ }^{47}$ Voters in the state passed the amendment by eighty-one percent of the vote. ${ }^{48}$

As political pressure mounted, Congress became involved and, in 1996, passed the Defense of Marriage Act (DOMA). ${ }^{49}$ The act had two main purposes. $^{50}$ The first was to declare that no state would be required to recognize same-sex marriages performed in other states. ${ }^{51}$ Second, DOMA provided that, when it came to federal law "the word 'marriage' means only a legal union between one man and one woman as husband and wife, and the word 'spouse' refers only to a person of the opposite sex who is a husband or a wife." 52 In other words, to the extent federal law conditioned marriage benefits on whether the couple was married in their state of residence, the federal government would exclude any same-sex marriages a state might recognize. Congress took this step even though at that time same-sex marriage was not recognized anywhere in the United States. ${ }^{53}$

constitutional amendments."); Julie L. Davies, State Regulation of Same-Sex Marriage, 7 GEO. J. GENDER \& L. 1079, 1080 (2006) ("Following the first failure of a statute banning marriage for same-sex couples in Hawaii, states began turning to state constitutional amendments to restrict marriage.").

${ }^{46}$ Kenneth P. Miller, Defining Rights in the States: Judicial Activism and Popular Response, 76 ALB. L. REV. 2061, 2087-88 (2013) (“Over time, voters in thirty-one states have approved constitutional amendments expressly limiting the definition of marriage to a union between a man and a woman or, in Hawaii's case, authorizing the legislature to do so.").

${ }^{47}$ Ala. CONST. ART. I, § 36.03.

${ }^{48}$ See Dave Woods, Crosspollination of Same-Sex Parental Rights Post-DOMA: The Subtle Solution, 46 ConN. L. REV. 1651, 1677 (2014).

${ }^{49}$ Mark A. Tumeo, Civil Rights for Gays and Lesbians and Domestic Partner Benefits: How Far Could an Ohio Municipality Go?, 50 CLEV. ST. L. REV. 165, 169 (2003) ("In 1996, the United States Congress capitulated to political pressure from the conservative religious right and passed the Defense of Marriage Act (hereinafter DOMA).")

${ }^{50}$ See United States v. Windsor, 570 U.S. 744, 752 (2013) (noting that "DOMA contains two operative sections").

${ }^{51} 28$ U.S.C. $\$ 1738 \mathrm{C}$ (2012) ("No State ... shall be required to give effect to any public act, record, or judicial proceeding of any other State ... respecting a relationship between persons of the same sex that is treated as a marriage under the laws of such other State.").

521 U.S.C. $\$ 7$ (2012).

${ }^{53}$ See Lee-Ford Tritt, supra note 17, at 881 ("Notably, at the time DOMA was enacted, neither same-sex marriage nor polygamous marriage was legal in any state, territory, or possession of the United States."). 
Nonetheless, just as events in Hawaii galvanized efforts to block nationwide marriage equality, members of the LGBTQ community began to hope that something many of them had assumed would never happen in their lifetime might instead become reality. ${ }^{54}$ As a result, after losing in Hawaii, a number of activists began to target other states. Just one year after Hawaii passed its constitutional amendment, those advocates scored a new victory when Vermont ruled that its prohibition on same-sex marriage violated the state's constitution, ordering the legislature "to consider and enact legislation consistent with" the "Common Benefits Clause" of the state constitution. ${ }^{55}$ The court did note, however, that "[w] hether this ultimately takes the form of inclusion within the marriage laws themselves or a parallel 'domestic partnership' system or some equivalent statutory alternative, rests with the Legislature." 56 In 2000, the Vermont legislature would adopt the latter approach, making Vermont-if not the first state to allow same-sex marriage - the first to institute civil unions for same-sex partners. ${ }^{57}$

After Vermont, progress toward legalized same-sex marriage slowed for a few years. Then, in 2003, the Supreme Court issued its opinion in Lawrence v. Texas. ${ }^{58}$ On its face, the case merely concerned the constitutionality of Texas' sodomy law, which criminalized homosexual but not heterosexual sodomy - a law that, according to the Court, implicated "liberty of the person both in its spatial and in its more transcendent dimensions." 59 Basing its decision on the Due Process and Equal Protection provisions of the Fourteenth Amendment, the Court ruled that the law was unconstitutional. In so ruling, the Court noted that "the fact that the governing majority in a State has traditionally viewed a particular practice as immoral is not a sufficient reason for upholding a law prohibiting the practice," ${ }^{60}$ explicitly overruling

54 See Christopher R. Leslie, Embracing Loving: Trait-Specific Marriage Laws and Heightened Scrutiny, 99 CORNELL L. REV. 1077, 1092 (2014) (noting how the decision "provided a glimmer of hope for same-sex couples that their country, or at least their state, might recognize their relationships in their lifetimes."); Tina C. Campbell, The "Determination of Marriage Act": A Reasonable Response to the Discriminatory "Defense of Marriage Act", 58 LOY. L. REV. 939, 946 (2012) (noting how Baehr v. Lewin brought hope to the same-sex marriage movement).

${ }^{55}$ Baker v. State, 744 A.2d 864, 887 (Vt. 1999). That clause provides as follows: "That government is, or ought to be, instituted for the common benefit, protection, and security of the people, nation, or community, and not for the particular emolument or advantage of any single person, family, or set of persons, who are a part only of that community." Vt. Const., ch. I, art 7.

56744 A.2d at 867.

${ }^{57}$ Vt. Stat. Ann. tit. 15, § 1204 (West 2010)

58539 U.S. 558 (2001).

${ }^{59} \mathrm{Id}$. at 562.

${ }^{60} \mathrm{Id}$. at 577 (quoting Bowers v. Hardwick, 478 U.S. 186, 216 (Stevens, J., dissenting)). 
its earlier decision in Bowers v. Hardwick. ${ }^{61}$

The Court was careful to try and limit the reach of Lawrence. In fact, Justice Kennedy's opinion went so far as to proclaim that " $[\mathrm{t}]$ he present case does not . . . involve whether the government must give formal recognition to any relationship that homosexual persons seek to enter." 62 To that point, however, Scalia dissented, saying "Do not believe it": 63

Today's opinion dismantles the structure of constitutional law that has permitted a distinction to be made between heterosexual and homosexual unions, insofar as formal recognition in marriage is concerned. If moral disapprobation of homosexual conduct is "no legitimate state interest" for purposes of proscribing that conduct; and if . . . " $[w]$ hen sexuality finds overt expression in intimate conduct with another person, the conduct can be but one element in a personal bond that is more enduring," what justification could there possibly be for denying the benefits of marriage to homosexual couples exercising " $[\mathrm{t}] \mathrm{h}$ liberty protected by the Constitution"? ${ }^{64}$

Scalia was not the only one to interpret the Lawrence majority opinion in this manner. Writing shortly after the opinion was released, a case summary in the Harvard Law Review had this to say about the opinion: "Lawrence suggests that remaining forms of government-sanctioned anti-gay discrimination-including laws barring same-sex marriage, gay adoption, and service in the armed forces by gays and lesbians who acknowledge their sexual orientation - must either be narrowly tailored to further a compelling government purpose or be invalidated." 65

In fact, just a few months after Lawrence was issued, Massachusetts would become the first state to formally extend marriage equality to samesex couples. ${ }^{66}$ In its 2003 decision, Goodridge v. Department of Public

${ }^{61} I d$. at 578 ("Bowers was not correct when it was decided, and it is not correct today. It ought not to remain binding precedent. Bowers v. Hardwick should be and now is overruled.").

${ }^{62}$ Id. at 578; see also John G. Culhane, Marriage, Tort, and Private Ordering: Rhetoric and Reality in LGBT Rights, 84 CHI.-KENT L. REV. 437, 461 (2009) ("For all of its affirming language and sympathetic tone, though, Lawrence also reiterates - via needless dictumthat the case is not about marriage.").

63539 U.S. at 604 (Scalia, J., dissenting).

${ }^{64} \mathrm{Id}$. at 604-05.

${ }^{65}$ The Supreme Court, 2002 Term-Leading Cases, 117 HARV. L. REV. 297, 298 (2003)

66 See Douglas Nejaime, Before Marriage: The Unexplored History of Nonmarital Recognition and Its Relationship to Marriage, 102 CAL. L. REV. 87, 166 (2014) (describing 
Health, the state's highest court ruled that "barring an individual from the protections, benefits, and obligations of civil marriage solely because that person would marry a person of the same sex violates the Massachusetts Constitution." ${ }^{\prime 7}$ In so ruling, the court quoted Lawrence: "Our obligation is to define the liberty of all, not to mandate our own moral code." 68 When it came to fashioning a remedy, the court did not strike down Massachusetts' existing marriage laws but instead borrowed an approach from the highest court in Ontario, Canada, which held: "The appropriate remedy is to declare invalid the existing definition of marriage to the extent that it refers to 'one man and one woman' and to reformulate the definition of marriage as 'the voluntary union for life of two persons to the exclusion of all others." "'69 Unlike Vermont, the Massachusetts court did not give the legislature the option of creating civil unions and, on May 17, 2004, Massachusetts began issuing marriage licenses to same-sex couples. ${ }^{70}$

Now that one state had officially extended the right to marry to same-sex couples, more states began to pass constitutional amendments aimed at insulating them from having to recognize same-sex marriages performed in other states. That would not stop other states, however, from following Massachusetts' lead. In 2008, the highest courts in Connecticut ${ }^{71}$ and California ${ }^{72}$ likewise ruled that the state constitutions protected the rights of same-sex couples to wed. In so ruling, the Connecticut high court rejected

the Massachusetts Supreme Judicial Court as "the first state supreme court decision opening marriage to same-sex couples").

67798 N.E.2d 941, 969 (Mass. 2003).

${ }^{68} \mathrm{Id}$. at 948 (quoting Lawrence v. Texas, 539 U.S. 558, 571 (2001)).

${ }^{69}$ Halpern v. Toronto (City), (2003) 172 O.A.C. 276, para. 148. The Goodridge court "concur[red] with this remedy, which is entirely consonant with established principles of jurisprudence empowering a court to refine a common-law principle in light of evolving constitutional standards." 798 N.E.2d at 969.

${ }^{70}$ See Mary L. Bonauto, Goodridge in Context, 40 HARV. C.R.-C.L. L. REv. 1, 7 (2005) ("For the plaintiff couples in the Goodridge case, May 17 was the most important day of their lives . . . . Others, too, were overwhelmed by the power of the government to acknowledge our humanity and our citizenship.").

${ }^{71}$ Kerrigan v. Commissioner of Public Health, 957 A.2d 407 (Conn. 2008).

${ }^{72}$ In re Marriage Cases, 183 P.3d 384 (Cal. 2008). California would, however, cease issuing marriage licenses in November of that year after voters passed Proposition 8, which amended the California constitution to define marriage as involving one man and one woman. See Scott L. Cummings \& Douglas NeJaime, Lawyering for Marriage Equality, 57 UCLA L. REV. 1235, 1297 (2010) ("The court, however, left intact the roughly eighteen thousand marriages that had occurred between the Marriage Cases decision and the passage of Proposition 8.").

Same-sex marriage would not resume in California until 2013 when the Supreme Court issued its decision in Hollingsworth v. Perry, which let stand the district court's ruling that Proposition 8 was unconstitutional. 570 U.S. 693 (2013) (holding that appellants lacked standing to appeal the district court's opinion). 
civil unions as an option for curing the constitutional violation: "Although marriage and civil unions do embody the same legal rights under our law, they are by no means equal. The former is an institution of transcendent historical, cultural and social significance, whereas the latter is not." 73 The following year, the Iowa Supreme Court would do the same, making it the first Midwestern state to do so. ${ }^{74}$ Later that year, Vermont earned the distinction of becoming the first state to legalize same-sex marriage not because the state's highest court demanded it, but through legislationlegislation that would define marriage as "the legally recognized union of two people." 75 From 2009 to 2012, three other states and the District of Columbia would likewise pass legislation extending the right to marry to same-sex couples. ${ }^{76}$

Although the same-sex marriage had thus far involved questions of state law, the issue would take on federal constitutional dimensions in 2013 when the Supreme Court struck down Section 3 of DOMA, which excludes samesex spouses from qualifying for federal marriage benefits. ${ }^{77}$ The case was U.S. v. Windsor and involved a same-sex couple, Edith Windsor and Thea Spyer, who had been in a relationship since $1963 .{ }^{78}$ The two women, who lived in New York, where they registered as domestic partners in 1993, and were married in Canada in $2007 .{ }^{79}$ In 2009, Spyer died, leaving her estate to Windsor. ${ }^{80}$ Had Windsor been male, she could have taken advantage of the marital exemption for federal estate tax, but because she was female, DOMA denied her that marital benefit, forcing her to pay over $\$ 300,000$ in estate taxes. ${ }^{81}$ Thus, Windsor argued that DOMA was unconstitutional, and the Supreme Court agreed, ruling that Section 3 was unconstitutional, characterizing it as violative of "basic due process and equal protection principles applicable to the Federal Government": 82

DOMA singles out a class of persons deemed by a State

73957 A.2d at 418.

${ }^{74}$ Varnum v. Brien, 763 N.W.2d 862 (Iowa 2009)

${ }^{75}$ Vt. Stat. Ann. tit. 15, § 8. Previously, it had read "Marriage is the legally recognized union of one man and one woman." See Calvin Massey, Public Opinion, Cultural Change, and Constitutional Adjudication, 61 Hastings L.J. 1437, 1448 n.47 (2010).

${ }^{76}$ See Obergefell v. Hodges, 135 S.Ct. 2584, 2615 (Roberts, J., dissenting) (identifying Vermont, New Hampshire, New York and Washington, D.C.)

${ }^{77}$ See supra notes 50-53 and accompanying text.

78570 U.S. 744, 753 (2013).

${ }^{79} \mathrm{Id}$. Despite the fact they married in Canada, New York did recognize the validity of their marriage. $I d$.

${ }^{80} \mathrm{Id}$.

${ }^{81} I d$. ("Because DOMA denies federal recognition to same-sex spouses, Windsor did not qualify for the marital exemption from the federal estate tax.").

${ }^{82}$ Id. at 769 . 
entitled to recognition and protection to enhance their own liberty. It imposes a disability on the class by refusing to acknowledge a status the State finds to be dignified and proper. DOMA instructs all federal officials, and indeed all persons with whom same-sex couples interact, including their own children, that their marriage is less worthy than the marriages of others. ${ }^{83}$

The Court concluded that "[b]y seeking to displace this protection and treating those persons as living in marriages less respected than others, the federal statute is in violation of the Fifth Amendment." 84

On the heels of Windsor, the marriage equality movement gained considerable steam. In his 2014 opinion in favor of marriage equality, Judge Richard Gergel of the federal District of South Carolina noted that "[i]n the approximately 17 months since the Windsor decision, federal courts in virtually every circuit and in every state with a same sex marriage ban have heard lawsuits challenging the constitutionality of such state law provisions." 85 A majority of those courts, including four federal courts of appeal, would ultimately rule in favor of same-sex couples looking to marry. ${ }^{86}$ Notably, however, one appellate court — the Sixth Circuit—reached the opposite conclusion and, in so doing, overturned lower court decisions in Kentucky, Michigan, Ohio and Tennessee. ${ }^{87}$ In late 2014, the Sixth Circuit issued its opinion, essentially holding that the voters and not the courts should decide the issue of same-sex marriage - an approach the dissent characterized as failing "to grapple with the relevant constitutional question." ${ }^{\text {" }}$ "That decision was DeBoer v. Sydney, but once the Supreme Court granted certiorari, it would be consolidated with another case and given a new name: Obergefell v. Hodges. ${ }^{89}$

The Court would use Obergefell to finally address the larger question of whether a state may constitutionally prohibit same-sex marriage. ${ }^{90}$ Although

${ }^{83} \mathrm{Id}$. at 775 .

${ }^{84} I d$. According to the Court, "the Fifth Amendment . . . withdraws from Government the power to degrade or demean in the way this law does." Id. at 774.

${ }^{85}$ Condon v. Haley, 21 F. Supp. 3d 572, 582 (D.S.C. 2014).

${ }^{86}$ Carl Tobias, Marriage Equality Comes to the Fourth Circuit, 75 WASH. \& LEE L. REV. 2005, 2008 (2018) ("The U.S. Courts of Appeals for the Fourth, Seventh, Ninth, and Tenth Circuits affirmed district invalidations.").

${ }^{87}$ DeBoer v. Snyder, 772 F.3d 388, 413 (6th Cir. 2014); see also Tom Watts, From Windsor to Obergefell: The Struggle for Marriage Equality Continued, 9 HARV. L. \& POL'Y REV. S52, S68 (2015) (noting that "the Sixth Circuit provided the desired circuit split").

88772 F.3d at 421 (Daughtrey, J., dissenting).

${ }^{89} 135$ S. Ct. 2584 (2015).

${ }^{90} \mathrm{Id}$. at 2593. 
the Court had previously held that "the right to marry is protected by the Constitution," 91 the precedent cases upon which that right had developed all involved laws that had clearly "presumed a relationship involving oppositesex partners." N2 Nonetheless, in his majority opinion, Justice Kennedy held that an analysis of those opinions "compels the conclusion that same-sex couples may exercise the right to marry." 93 Specifically, the Court identified four essential "principles and traditions" related to marriage that justified its classification as a fundamental right-principles and traditions that, according to the Court, "apply with equal force to same-sex couples.",94

First, going back to its decision in Loving, the Court noted that "the right to personal choice regarding marriage is inherent in the concept of individual autonomy," recognizing that "[t]here is dignity in the bond between two men or two women who seek to marry and in their autonomy to make such profound choices." 96 Second, according to the Court, marriage is a fundamental right because the institution "supports a two-person union unlike any other in its importance to the committed individuals." 97 Third, the Court held that marriage "safeguards children and families and thus draws meaning from related rights of childrearing, procreation, and education." 98 Citing Windsor, where the Court noted how laws prohibiting same-sex marriage "harm and humiliate the children of same-sex couples," 99 the Court explained that "[b]y giving recognition and legal structure to their parents' relationship, marriage allows children 'to understand the integrity and closeness of their own family and its concord with other families in their community and in their daily lives." 100 Finally, the Court justified the fundamental nature of the right to marry, noting that marriage is "the foundation of the family and of society, without which there would be neither civilization nor progress."101

${ }^{91} I d$. at 2598.

${ }^{92}$ Id. at 2589. The Court did acknowledge, however, Baker v. Nelson, 409 U.S. 810 (1972). See supra notes 28-32 and accompanying text. Obergefell, of course, overruled Baker. Id. at 2605.

${ }^{93}$ Obergefell, 135 S. Ct. at 2599.

${ }^{94} \mathrm{Id}$.

${ }^{95} I d$.

${ }^{96} I d$. ("The nature of marriage is that, through its enduring bond, two persons together can find other freedoms, such as expression, intimacy, and spirituality.").

${ }^{97}$ Id. As the Court explained, "[Marriage] offers the hope of companionship and understanding and assurance that while both still live there will be someone to care for the other." Id.

${ }^{98}$ Id. (citing Pierce v. Soc'y of Sisters, 268 U.S. 510 (1925); Meyer v. Nebraska, 262 U.S. 390, 399 (1923)).

${ }^{99}$ Obergefell, $135 \mathrm{~S}$. Ct. at 2600-01.

${ }^{100} I d$. at 2600 (quoting United States v. Windsor, 570 U.S. 744, 772 (2013)) ("Marriage also affords the permanency and stability important to children's best interests.").

${ }^{101} I d$. at 2601 (quoting Maynard v. Hill, 125 U.S. 190, 211 (1888)). 
Having distilled the right to marry into those four components, each of which justifying its recognition as a fundamental right, the Court found no basis for excluding same-sex couples from that right:

Same-sex couples, too, may aspire to the transcendent purposes of marriage and seek fulfillment in its highest meaning. [Although the] limitation of marriage to oppositesex couples may long have seemed natural and just, . . . its inconsistency with the central meaning of the fundamental right to marry is now manifest. With that knowledge must come the recognition that laws excluding same-sex couples from the marriage right impose stigma and injury of the kind prohibited by our basic charter. ${ }^{102}$

Accordingly, the Court held that the Due Process Clause prohibits states from denying same-sex couples the ability to marry on terms equal to those of opposite-sex couples, paving the way for same-sex couples around the country to immediately begin exercising their Constitutional right to marrysomething many of them had waited decades to do.

\section{OBERGEFELl AND PRE-EQUALity “MARRIAGES”}

At its most basic level, Obergefell permitted same-sex couples to prospectively enter into formal marriages. What it did not do was give legal effect to the relationships they had entered into years earlier when marriage was not an option. ${ }^{103}$ Thus the question arises as to whether those couples were entitled to any credit for the time they had spent waiting for marriage equality and, if so, how such credit was to be determined. After all, Obergefell made clear that same-sex couples were not only entitled to the right to wed but were likewise entitled to do so "on the same terms and conditions as opposite-sex couples." "104 Just two years after Obergefell, the Court issued Pavan v. Smith, a per curium order in which a majority reiterated that understanding when it characterized Obergefell as being committed "to provide same-sex couples 'the constellation of benefits that the States have linked to marriage." "105

102 Id. at 2602.

103 See Rhodes, supra note 17, at 433 ("The Supreme Court could have exceeded the presented issues and ordered remedial backdating in Obergefell as a constitutional minimum-but it did not.").

104 Obergefell, 135 S. Ct. at 2593.

105 Pavan v. Smith, 137 S. Ct. 2075, 2077 (2017) (quoting Obergefell, 135 S. Ct. at 2601). 
As the remainder of this Part makes clear, however, there are a number of marital benefits that would have accrued to those in same-sex relationships if not for the unconstitutional denial of their right to wed. Thus, failure to count the years same-sex couples spent in an informal marriage-like state would undermine Obergefell's promise of "liberty and equality under the Constitution." 106 After discussing several of the marital benefits that fall into this category, this Part will then look to the disparate approaches states have taken when confronted with the issue of whether to "backdate" marriages for same-sex couples.

\section{A. Benefits Conditioned on Length of Marriage}

This Article began by discussing Michael Ely's pursuit of social security benefits, which is but one of the "constellation of benefits" tied to length of marriage. ${ }^{107}$ In that example, the Social Security Administration refused to recognize Ely as a surviving spouse given that he was unable to satisfy the Act's requirement that he was married to the insured for nine months. ${ }^{108}$ Other federal benefits have similar restrictions. For instance, the statute governing pension benefits for surviving spouses of federal employees has the same nine-month requirement. ${ }^{109}$ Additionally, the federal statute that deals with pension benefits for surviving spouses of military veterans withholds eligibility "unless such surviving spouse was married to such veteran . . . before the expiration of fifteen years after the termination of the period of service in which the injury or disease causing the death of the veteran was incurred or aggravated; or . . f for one year or more." 110 Beyond benefits related to surviving spouses, federal law likewise imposes length of marriage restrictions in the area of immigration law. For instance, one can petition to have a spouse classified as an immediate relative only after "the alien has resided outside the United States for a 2-year period beginning after the date of the marriage."111

At the state level, there are additional benefits that are conditioned on being married for a certain amount of time. In Arkansas, for instance, a surviving spouse's ability to take an elective share is conditioned on having "been married to the decedent continuously for a period in excess of one (1) year."112 Similarly, a number of other states calculate the amount of the

${ }^{106}$ Obergefell, 135 S. Ct. at 2604.

${ }^{107}$ See supra note 6 and accompanying text.

${ }^{108}$ And this is but one of the Social Security benefits tied to length of marriage. For an excellent discussion of others see Nicolas, supra note 17, at 408-12.

${ }^{109}$ See 5 U.S.C. $\S 8341(\mathrm{a})(1)(\mathrm{A}),(\mathrm{a})(2)(\mathrm{A})(2012)$.

110 See 38 U.S.C. $\S \S 1102(\mathrm{a})(2), 1304,1541(\mathrm{f})(2012)$.

${ }^{111}$ See 8 U.S.C. $\S \S 1154(\mathrm{~g})(2012)$.

112 See Ark. Code AnN. § 28-39-401(a) (2015). "Elective share" refers to "state law 
elective share by looking at how long the parties were married. ${ }^{113}$ A number of states condition certain divorce protections on the length of the marriage. For instance, when it comes to the decision of whether to award alimony and in what amount, some states have statutes requiring courts to consider the length of the marriage. ${ }^{114}$ Indeed, in the absence of a statutory directive, several states have held that there is a rebuttable presumption of permanent alimony if the marriage was "long-term." 115 Many states also consider the length of the marriage when determining property distribution. ${ }^{116}$ A divorce statute in Washington, for instance, directs that "a court shall . . . make such disposition of the property and the liabilities of the parties . . . after considering all relevant factors including... . [t]he duration of the marriage." 117

Beyond absolute length of marriage, many marital benefits at the state level are conditioned on whether the parties were married during the occurrence of certain events. One of the most notable examples relates to property distribution. Upon divorce, the majority of states equitably divide a couple's marital property between the two parties, but not each spouse's separate property, which remains with the spouse who owns it. ${ }^{118}$

[that] gives surviving spouses the right to make claims against their deceased spouses' estates, even if the deceased spouses explicitly disinherited them." Laura A. Rosenbury, Two Ways to End A Marriage: Divorce or Death, 2005 UTAH L. REV. 1227, 1245 (2005).

${ }^{113}$ See, e.g., MinN. STAT. ANN. § 524.2-202 (West).

114 See, e.g., Lyudmila Workman (2011), Alimony Demographics, 20 J. ConTEMP. LEGAL IsSUES 109, 110 (2012) ("Length of marriage is one significant factor in determining the distribution of alimony awards.").

${ }^{115}$ See id. (discussing a study that found "that women who had been housewives in marriages lasting 10 years or more were much more likely to be awarded support than those in marriages of less than five years, and that the likelihood of receiving alimony increased proportionately to the length of the underlying marriage"); see also Erez Aloni, The Puzzle of Family Law Pluralism, 39 HARV. J. L. \& GENDER 317, 341 (2016) (noting that "many states now restrict permanent alimony to long-term marriages").

116 See, e.g., Swanson v. Swanson, 921 N.W.2d 666, 670 (N.D. 2019) (“A long-term marriage generally supports an equal property distribution."); Impullitti v. Impullitti, 15 N.W.2d 261, 264 (Mich. Ct. App. 1987) ("Factors to be considered in the division are the property's source, contribution towards its acquisition, length of the marriage, and the needs and earning capacities of the parties.”).

${ }^{117}$ See CONN. GEN. STAT. ANN. § 46b-81 (West) ("In fixing the nature and value of the property, if any, to be assigned, the court . . . shall consider [among other things] the length of the marriage."); IOWA CODE ANN. § 598.21 (West) ("The court shall divide all property, except inherited property or gifts received or expected by one party, equitably between the parties after considering [among other things] [t]he length of the marriage.").

${ }^{118}$ See ANNE LAQUER ESTIN, DOMESTIC RELATIONSHIPS: A CONTEMPORARY APPROACH 713 (2019) ("Most states are 'marital property' states, which require the divorce court to classify the property owned by the spouses at the time of divorce as either marital or separate, and then authorize the court to divide all marital property."). Community property states follow a similar approach, but label the property acquired during marriage as "community 
Determining whether a particular item of property qualifies as marital or separate typically relates to when that property was acquired-if before marriage, separate; if during the marriage, marital. ${ }^{119}$ For an economically dependent spouse, this distinction can be crucial, especially if the most valuable items of property are ultimately declared the separate property of the other spouse.

To illustrate, consider a same-sex couple who entered into a committed relationship in 2005. The two would have married had they had the right to do so, but instead were forced to wait until 2015 when Obergefell finally ushered in marriage equality. The two immediately married but then divorced three years later. In many states, any property the two had acquired between 2005 and 2015 would be considered separate and, thus, not subject to division upon divorce. Had the couple been permitted to wed in 2005, however, that same property would have likely been classified as divisible, marital property. Similar marital benefits that are conditioned on the parties being married at certain point in time include the marital privilege, which only protects communications made between two people who were married at the time of the communication; ${ }^{120}$ the ability to bring a claim for loss of consortium, which requires the claimant to have been married to the injured party at the time of the injury; ${ }^{121}$ and the marital presumption, which presumes the spouse of the mother is the child's second parent but only if the two were married when she gave birth. ${ }^{122}$

property," a designation that influences the "management and use" of that property not only when the marriage ends, but during the marriage as well. Id. at 714. A minority of states follow the "hotchpot" approach, whereby all property is subject to division regardless of when it was acquired. Marsha Garrison, Is Consent Necessary? An Evaluation of the Emerging Law of Cohabitant Obligation, 52 UCLA L. REV. 815, 836 n.76 (2005) (noting that only 14 states "permit[] the division of premarital assets").

119 There are typically exceptions, however, for property acquired during marriage as a result of inheritance or gift. See, e.g., ARIZ. REV. STAT. ANN. § 25-213 (“A spouse's real and personal property that is owned by that spouse before marriage and that is acquired by that spouse during the marriage by gift, devise or descent, . . . is the separate property of that spouse.") (emphasis added); see also Carla M. Roberts, Worthy of Rejection: Copyright As Community Property, 100 YALE L.J. 1053, 1059-60 (1991) ("Separate property typically is anything an individual owned prior to entering a marriage, income received from separate property, and property received by descent, devise, or gift during the marriage.").

120 See Steven A. Young, Retroactive Recognition of Same-Sex Marriage for the Purposes of the Confidential Marital Communications Privilege, 58 WM. \& MARY L. REV. 319,330 (2016) ("[I]t is critically important that the privilege requires 'spouses,' meaning the two parties must be married at the time the communication was made.").

121 See infra notes 140-148 and accompanying text.

122 See Dara E. Purvis, The Origin of Parental Rights: Labor, Intent, and Fathers, 41 FLA. ST. U. L. REV. 645, 662 (2014) ("Long before paternity tests were available, in other words, the marital presumption assumed that married women did not bear children fathered by men other than their husbands."); see also infra note 135 and accompanying text. 
At the same time, one cannot lose sight of the marital benefits tied to the very fact of marriage and how the availability of those benefits have been impacted by same-sex relationships that predated marriage equality. For instance, there are a number of individuals living today who never formalized their same-sex relationships simply because their partners died before they were legally permitted to wed. For those survivors, the timing of their partner's deaths caused significant legal harm. Consider, for instance, Helen Thornton and Margery Brown, who were in a committed relationship in Washington for twenty-seven years. ${ }^{123}$ The two women met in 1979, and their relationship lasted until 2006 when Brown died of cancer. ${ }^{124}$ Given that samesex marriage was not permitted in Washington state until 2012, the two women were unable to marry. ${ }^{125}$ Accordingly, when Thornton filed for social security benefits as a surviving spouse, her application was denied. ${ }^{126}$

In addition, there are a number of same-sex relationships that the parties dissolved prior to marriage equality. The potential harm to individuals in those relationships stems from the fact that, had they been permitted to marry, those relationships might have been marital and thus could only have been dissolved in accordance with the protections afforded by the states' divorce laws. For example, in 2004, Kimberly Sutton proposed marriage to Charlene Ramey. ${ }^{127}$ The Oklahoma couple spent the next eight and a half years living together and holding themselves out as a committed couple. ${ }^{128}$ The two even agreed to become parents. ${ }^{129}$ Using artificial insemination, Kimberly became pregnant, and gave birth to a son in 2005. ${ }^{130}$ Nonetheless, Kimberly acknowledged Charlene as the child's other parent. ${ }^{131}$ In fact, Charlene served as primary caregiver to the child, who referred to Charlene as "mom." "132 Likewise, the trio held themselves out to friends and relatives as

\footnotetext{
${ }^{123}$ The details of this case are all taken from the complaint filed on their behalf by Lambda Legal. See https://www.lambdalegal.org/in-court/legaldocs/thornton_wa_20180925_complaint.

${ }^{124} I d$.

${ }^{125} \mathrm{Id}$.

${ }^{126} \mathrm{Id}$.

${ }^{127}$ Ramey v. Sutton, 362 P.3d 217, 220 (Okla. 2015) ("Ramey ... wore a diamond ring to reflect their mutual commitment.).

${ }^{128} I d$. at 219.

${ }^{129} \mathrm{Id}$.

${ }^{130} I d$. Although "[a] friend of the couple agreed to be the donor," the court noted that "[t]he donor understood and agreed that Ramey and Sutton would co-parent and raise any child conceived as their own and that he did not have any obligations." Id. at n. 4.

${ }^{131} I d$. ("Sutton prepared a baby book for their child identifying both Sutton and Ramey as parents. Sutton gave a card to Ramey congratulating her on becoming a 'mother' to their son and that she would be a wonderful mom.").

${ }^{132} I d$. The child would not refer to Kimberly as her mother "until the age of five or six." Id. ("Even today, their child will sometimes refer to Sutton, the biological mom as Kimberly
} 
a family. ${ }^{133}$

When the relationship between the two women ultimately ended, Kimberly argued that Charlene was not entitled to custody or visitation given that she was not the biological parent, and the two had never married. ${ }^{134} \mathrm{Had}$ the two wed at any point prior to dissolving their relationship, there would have been no question that Charlene was a legal parent. ${ }^{135}$ Charlene did ultimately prevail, but it was not because the court was willing to consider the quality of the relationship during a time when marriage was an impossibility. Instead, the court ruled that, "although the biological mother enjoys many rights as a parent, it does not include the right to erase a relationship that she voluntarily created and fostered with their child."136

Thus, for the LGBTQ Americans who were lucky enough to have lived to see marriage equality become the law of the land, they still face discrimination when it comes to receiving "the same terms and conditions as opposite-sex couples." 137 Specifically, for individuals today who were in same-sex relationships that would have been marriages had the law not prevented them from formalizing their unions, they are being denied a number of protective benefits. Although these benefits are likewise denied opposite-sex couples whose relationships ended before they could marry or who spent years cohabitating prior to a formal marriage, there is a key difference: for same-sex couples, marriage was a legal impossibility.

\section{B. State Responses}

The concept of formal marriage equality is still relatively new and, as such, there are a number of questions regarding the reach of Obergefell with which the law must still grapple. ${ }^{138}$ Justice Kennedy's equal protection

and not as "mom."').

133 Id.

${ }^{134} \mathrm{Id}$.

135 OKLA. STAT. AnN. TIT. 10, $§ 7700-204$ (West) (stating that "[a] man is presumed to be the father of a child if . . [h] e and the mother of the child are married to each other and the child is born during the marriage"). Although the statute is written in gendered terms, the Supreme Court has ruled that a state cannot extend the marital presumption to opposite-sex marriages without also extending it to same-sex marriages. See Pavan v. Smith, 137 S.Ct. 2075 (2017).

${ }^{136} \mathrm{Id}$. at 221. In ruling for Ramey, however, the court did note that " $[\mathrm{t}]$ he couple's failure to marry cannot now be used as a means to further deprive the nonbiological parent, who has acted in loco parentis, of a best interests of the child hearing."

${ }^{137}$ Obergefell, 135 S. Ct. at 2593.

138 Craig Green, Turning the Kaleidoscope: Toward A Theory of Interpreting Precedents, 94 N.C. L. REV. 379, 467 (2016) (noting that Obergefell "resolved doctrinal debates over same-sex marriage, but . . raised unanswered questions concerning LGBT discrimination, polygamy, and other forms of constitutional liberty"). 
analysis, for instance, did little to illuminate the standard of review that applies to discrimination on the basis of sexual orientation. ${ }^{139}$ What does seem clear, however, in the wake of both Obergefell and Pavan is that whatever marital benefits a state extends to opposite-sex couples, it must likewise extend to same-sex couples. The question arises, however, as to how states are to apportion marital benefits to same-sex couples who were prohibited by law from marrying. Since Obergefell the issue has arisen in a variety of contexts, and not surprisingly, the states have taken a number of different approaches.

Even before Obergefell, the Supreme Court of Connecticut became one of the earliest courts to rule that same-sex couples are entitled to marital benefits if - but for the prohibition against same-sex marriage - they would have wed at an earlier date. In Mueller v. Tepler, Margaret Mueller and Charlotte Stacey were in a longtime relationship that began in $1985 .{ }^{140} \mathrm{In}$ 2001, Margaret's physician diagnosed and subsequently treated her for ovarian cancer when, in fact, she was suffering from cancer of the appendix. ${ }^{141}$ Left untreated, Margaret's cancer progressed to the point where surgery was no longer an option, and she died in 2009. ${ }^{142}$ In 2006, however, she brought a medical malpractice claim, which included a claim by Charlotte for loss of consortium. ${ }^{143}$ The defendants moved to strike Charlotte's claim on the basis that, at the time of the alleged negligence, she and Margaret were not married as is required by the state's law regarding loss of consortium claims. ${ }^{144}$ Although the two did enter into a civil union in 2005 pursuant to Connecticut law, the plaintiffs had alleged that the medical malpractice occurred before that date. ${ }^{145}$

Nonetheless, the court ruled that the requirement that the plaintiff must have been married to the injured party at the time of the injury "only has logical force ... if the couple was capable of entering into a 'formal marriage

139 See, e.g., Peter Nicolas, Reconstruction, 10 UC IRvine L. REV. 937, 985 (2020) ("[T]he Court appeared to apply something more rigorous than traditional rational basis review [but] never articulated a standard of review.").

${ }_{140}$ Mueller v. Tepler, 95 A.3d 1011, 1015 (Conn. 2014).

141 Id. (noting that the doctor "either failed to review the pathology report or misinterpreted its findings").

142 Id. ("Although the error was discovered in April 2005, Mueller's cancer had progressed to a stage where some of the tumors no longer could be removed surgically.").

${ }^{143} \mathrm{Id}$.

${ }^{144}$ Id.; see also Gurliacci v. Mayer, 590 A.2d 914, 931-32 (Conn. 1991) (“[V]irtually all of the jurisdictions that have considered the question take the position that '[a]n action for loss of consortium cannot be maintained unless the plaintiff was married to the injured person at the time of the actionable conduct."') (quoting Briggs v. Butterfield, 479 N.Y.S.2d 758 (N.Y. App. Div. 1984)).

${ }^{145} I d$. The court did note, however, that the two were not permitted to enter into the civil union until a year after the doctor had stopped treating Margaret. Id. at n. 4. 
relation' prior to the injury." 146 Because that option was not available to Margaret and Charlotte, the court expanded the ability to bring a loss of consortium claim "to members of couples who were not married when the tortious conduct occurred, but who would have been married if the marriage had not been barred by state law." 147 In light of that expansion, the court remanded the case to determine whether the two women's relationship met that test. ${ }^{148}$

The following year, an Oregon court would adopt a similar test. There, Karah and Lorrena Madrone held a commitment ceremony in 2005. ${ }^{149}$ Two years later, the two women decided to have a child by artificial insemination, and Lorrena agreed to carry the child. ${ }^{150}$ Afterwards, the two women both changed their last names to Madrone and registered as domestic partners pursuant to Oregon law. ${ }^{151}$ The relationship between the two women "deteriorated," and in 2012 Karah filed for a dissolution of the domestic partnership. ${ }^{152}$ She also sought a declaration that she was the legal parent of the child born to Lorrena. ${ }^{153}$ Karah did so by relying on an Oregon statute that provided that a husband of a woman who conceives by artificial insemination is presumed (assuming he consented to the insemination) to be the legal father. ${ }^{154}$ Although Oregon courts had previously extended the statute's protections to same-sex partners, ${ }^{155}$ Lorrena objected on the basis that the two women did not enter into a domestic partnership until after the child was born. ${ }^{156}$ The court rejected her argument, however, and held that "choice is the key to determining whether [the Oregon statute] applies to a particular same-sex couple": 157

${ }^{146} I d$. at 1017 (quoting plaintiff's objection to defendants' motion to strike).

${ }^{147} \mathrm{Id}$. at 1023.

${ }^{148}$ Id. at $1030-31$.

${ }^{149}$ In re Madrone, 350 P.3d 495, 497 (Or. Ct. App. 2015).

${ }^{150} \mathrm{Id}$.

${ }^{151} I d$. at 498 n. 1.

${ }^{152} I d$. at 496.

${ }^{153}$ Id. ("Petitioner alleged that, at the time of R's conception and birth, she was respondent's "domestic and life partner," that she and respondent had planned the pregnancy with the intent to raise the child together, and that she had consented to the artificial insemination procedure.").

${ }^{154} I d$. at 498 (the statute provides the same rights to the mother's husband "as if the child had been naturally and legitimately conceived by the mother and the mother's husband." (quoting OR. REV. STAT. ANN. § 109.243 (West)).

155 See Shineovich \& Kemp, 214 P.3d 29, 40 (Or. Ct. App. 2009) ("extend[ing] the statute so that it applies when the same-sex partner of the biological mother consented to the artificial insemination.").

${ }^{156}$ In re Madrone, 350 P.3d at 499 (quoting Lorrena's argument that "the protections afforded [by the Oregon statute] apply to domestic partners, not simply people in a relationship").

${ }^{157} I d$. at 501 . 
Given that same-sex couples were until recently prohibited from choosing to be married, the test for whether a same-sex couple is similarly situated to the married opposite-sex couple contemplated in [the statute] cannot be whether the same-sex couple chose to be married or not. Rather, the salient question is whether the same-sex partners would have chosen to marry before the child's birth had they been permitted to. ${ }^{158}$

For those reasons, the case was remanded to determine whether the "couple would have married had that choice been available." 159

The Connecticut and Oregon cases both arose in states where same-sex couples, even before they obtained the right to marry, had the option of entering into a civil union or domestic partnership. Since Obergefell, many of those states have adopted legislation concerning how time spent in these "alternative species of quasi-marriage" 160 will count toward the length of the marriage. Specifically, as Peter Nicolas explains, seven states that permitted same-sex couples to enter into domestic partnerships or civil unions preObergefell have since "created a seamless mechanism for converting civil unions or domestic partnerships to marriages." ${ }^{161}$ Of those, about half have legislated that the marriage began on the date the relationship was converted to a formal marriage while the remainder set the date as when the couple first entered into the domestic partnership or civil union. ${ }^{162}$ Although the latter approach allows the same-sex couple to count more of their actual relationship toward the subsequent marriage, it still only applies to those portions that came after the couple entered into the domestic partnership or civil union-legal options that may not have been available until after the couple had already been in a relationship for many years.

Nonetheless, such an approach is still superior to that being taken in states that failed to even offer civil unions or domestic partnerships. In the few cases that have arisen in those states, courts have simply refused to grant marital benefits to same-sex couples whose relationships spanned time

${ }^{158} I d$. (emphasis in original).

${ }^{159} \mathrm{Id}$. at $502,503$.

${ }^{160}$ Andersen v. King Cty., 2004 WL 1738447, at*12 (Wash. Super. Aug. 4, 2004).

${ }^{161}$ Nicolas, supra note 17, at 405.

${ }^{162}$ Id. at 405-06; Compare WASH. REV. CodE ANN. § 26.60.100 (West) (“[T]he date of the original state registered domestic partnership is the legal date of the marriage.") with 15 R.I. GEN. LAWS ANN. § 15-3.1-13 (West) ("For purposes of determining the legal rights and responsibilities involving [married] individuals who previously entered into a civil union in this state, ... the date of the recording of the marriage certificate shall be the operative date by which legal rights and responsibilities are determined."). 
periods in which they were prohibited from marrying. Consider, for instance, a Michigan case involving two women, Deanna and Johanna Mabry, who were in a relationship that began in 1995 and lasted until 2010. ${ }^{163}$ During that time, the two bought a house together, participated in a commitment ceremony, and Johanna even took Deanna's last name. ${ }^{164}$ Most relevant to the subsequent litigation, however, was the fact that the relationship produced three children. ${ }^{165}$ Johanna was the biological mother, having conceived using an anonymous donor. ${ }^{166}$ Nonetheless, Deanna's role in the children's lives was "significant" in that she "provided [them] with health insurance, she was the sole financial provider for the family, and she provided care and guidance to the children." 167 In fact, Johanna's will provided that, "in the event of her death, [Deanna] would be the children's legal guardian and conservator."168

However, when the parties ended their relationship and Deanna petitioned for custody, the Michigan court ruled that she lacked standing because she was never formally married to the children's mother. ${ }^{169}$ Unlike the courts in Connecticut and Oregon, ${ }^{170}$ the court refused to even consider whether the couple would have married had they been permitted to do so. A year earlier, a court in Florida, on very similar facts, reached the same conclusion. ${ }^{171}$ Thus, in comparison to states like Connecticut and Oregon, states that never adopted alternatives to marriage currently appear to be more hostile to backdating claims by those in same-sex relationships.

There is, however, one exception and that is the handful of states that permit informal or common-law marriage. A survey of decisions from those states reveals that some have been willing to offer relief by finding that the couple had effectuated a common-law marriage. To illustrate, consider the South Carolina case of Debra Parks, who ended a forty-year relationship with her partner in 2017. ${ }^{172}$ During this time, the two had bought a house and

${ }^{163}$ Mabry v. Mabry, 882 N.W.2d 539, 540 (Mich. 2016) (McCormack, J., dissenting).

${ }^{164} \mathrm{Id}$. (Additionally, the two took additional steps, including "filing a declaration of domestic partnership, ... entering a formal domestic-partnership agreement, ... and entering into a marriage covenant in the form of a ketubah").

${ }^{165} \mathrm{Id}$.

${ }^{166} \mathrm{Id}$.

${ }^{167} I d$. (noting that all three children "were biological children of the defendant but took the plaintiff's last name and were parented by both the defendant and the plaintiff').

${ }^{168} \mathrm{Id}$.

${ }^{169}$ Id. at 541 ("The order held that the plaintiff did not have standing to bring a custody action pursuant to the equitable-parent doctrine because that doctrine is only available to a parent who was married.").

${ }^{170}$ See supra notes 140-159 and accompanying text.

171 See Willis v. Mobley, 171 So. 3d 739 (Fla. Dist. Ct. App. 2015) (unpublished disposition).

172 See Andrew Dys, Same-Sex Legal Groundbreaker: Judge Says Rock Hill Couple Married In S.C. For Decades, THE HERALD (March 19, 2017), 
"other property together, had joint bank accounts, used each other on tax documents, and lived together until 2016." 173 The couple resided in South Carolina, which did not permit same-sex marriage until 2014. ${ }^{174}$ South Carolina does, however, recognize common-law marriage. ${ }^{175}$ When Parks sued to have her relationship declared a common-law marriage, the judge agreed. ${ }^{176}$ In essence, the court ruled that not only had the two entered into a common-law marriage, but that it had commenced when Parks divorced her husband in 1987-twenty-seven years before South Carolina would begin allowing same-sex marriage. ${ }^{177}$ Other common law marriage states have reached similar results when dealing with individuals whose same-sex partners died before they were able to legally wed. ${ }^{178}$

Because very few states permit common law marriage, however, the vast majority of states have had to fashion new tests for dealing with those in same-sex relationships that predated marriage equality. And, as detailed earlier, those states have done so with varying approaches and with divergent opinions as to what true marriage equality entails. That itself is problematic, in light of the fact that the right to marry is a constitutionally protected right. ${ }^{179}$ As such there necessarily must exist some standards to which all states must adhere. Of course, family law is largely within the primary province of the states, and as such, it would be unreasonable to expect all states to have an identical response to this issue. ${ }^{180}$ In fact, as Professor Charles Rhodes as pointed out, "family law courts, as a rule, traditionally

https://www.heraldonline.com/news/local/article139540723.html\#storylink=cpy

${ }^{173} I d$. According to Park, "We were a family, even when society didn't accept it." Id.

${ }^{174} \mathrm{Id}$.

${ }^{175} \mathrm{Id}$.

${ }^{176} I d$. According to the Judge, "Quoting William Shakespeare, 'A rose by any other name would smell as sweet. ... The law established by the U.S. Supreme Court in Obergefell ... should be applied retroactively in South Carolina." Id.

${ }^{177} \mathrm{Id}$.

178 See Nicolas, supra note 17, at 416-18 (collecting and discussing cases); Steven A. Young, Retroactive Recognition of Same-Sex Marriage for the Purposes of the Confidential Marital Communications Privilege, 58 WM. \& MARY L. REV. 319, 338-43 (2016) (same).

${ }^{179}$ See Michael J. Higdon, Polygamous Marriage, Monogamous Divorce, 67 DuKE L.J. 79, 96 (2017) ("[T]he Court has declared that, under the substantive component of the Due Process Clause of the Fourteenth Amendment, the right to marry is a fundamental right.").

${ }^{180}$ See Milton C. Regan, Jr., Reason, Tradition, and Family Law: A Comment on Social Constructionism, 79 VA. L. REV. 1515, 1524 (1993) (“[A] cardinal tenet of United States jurisprudence is that family law is primarily the province of individual states-a principle that explicitly invites the codification of diverse particular judgments about how family life should be arranged."); Elizabeth G. Patterson, Unintended Consequences: Why Congress Should Tread Lightly When Entering the Field of Family Law, 25 GA. ST. U. L. REV. 397, 406 (2008) ("Leaving family law to the states, however, allows diversity to exist within the United States, and individuals whose values differ from those of the majority in one location have the alternative of emigrating to another, more compatible, community."). 
have broad judicial discretion in adjudicating disputes and fashioning just outcomes." 181 Nonetheless, because "federal constitutional rights are understood to extend equally across the land,"182 there are limits to how divergent states can be when it comes to resolving the issue of backdating same-sex marriage. ${ }^{183}$

Thus, a more consistent remedy is necessary if states are to remedy the harms that many individuals from same-sex relationships continue to experience as a result of the unconstitutional laws that had long prevented them from marrying.

\section{THE LAW OF INFORMAL FAMILY CREATION}

States that refuse to consider the pre-equality portion of a same-sex couple's relationship are producing two separate, but related harms. First, they are short-changing individuals in same-sex marriages who seek marital benefits tied to length of marriage. ${ }^{184}$ Second, those states completely denying all marital benefits to those who were in same-sex relationships that ended (either through dissolution or divorce) prior to the time marriage became a legal option. Both harms run counter to the Court's holding in Obergefell, and thus a new remedy is required.

When it comes to formulating an appropriate remedy, however, it is important to first recognize that states are not operating on a blank slate when it comes to awarding family-like benefits to individuals who lack formal family relationships. Instead, the states already possess a number of equitable doctrines that operate in a variety of different contexts to do just thatdoctrines that can greatly assist the courts in crafting a new remedy to protect same-sex couples whose relationships pre-dated marriage equality. These existing remedies are operate against a backdrop where, despite the robust legal protections that exist for American families, there is little consensus on the precise legal definition of "family." "185 When people talk of "starting a

${ }^{181}$ Rhodes, supra note 17 , at 432.

182 Wayne A. Logan, Contingent Constitutionalism: State and Local Criminal Laws and the Applicability of Federal Constitutional Rights, 51 WM. \& MARY L. REV. 143, 169 (2009).

${ }^{183}$ Michael J. Higdon, Constitutional Parenthood, 103 IowA L. REV. 1483, 1490 (2018) ("[A]11 constitutional rights, it must necessarily possess some core limits that bind the states.").

${ }^{184}$ See Nicolas, supra note 17, at 397 (“'[M] any same-sex relationships appear artificially short in endurance when measured solely by reference to the couple's civil marriage date."

${ }^{185}$ Kirsten Korn, The Struggle for the Child: Preserving the Family in Adoption Disputes Between Biological Parents and Third Parties, 72 N.C. L. REV. 1279, 1291 (1994) ("Although the Supreme Court has held that the Constitution protects various aspects of the family, as well as the parent-child relationship, determining what constitutes a "family" and who may be considered "parents" for purposes of such protection has proved difficult."). 
family," one typically imagines marriage and the eventual addition of children, either through birth or adoption. The reality, however, is much more complicated, and over the years that complexity has only grown. ${ }^{186}$ Couples may get married, or they may not. Perhaps the couple thought they were married when, in reality, the marriage was void for some reason. The two may have children together, or they may not. Perhaps they end up raising children who only have a biological relationship with one of them. Maybe the nonbiological parent adopts the new children, but perhaps not. Maybe they agree to take in a child from a friend or relative and, despite an intent to do so, never get around to formally adopting the child.

Family law is no stranger to dealing with any of these scenarios, consistently drawing upon its "built-in flexibility to adapt to changing times." 187 And, indeed, over the years states have developed a number of doctrines that permit courts to extend familial rights even to those who failed to formally create legal family relationships. What follows is a brief survey of five different examples that courts have relied upon in order to fashion a new remedy for same-sex couples whose "marriages" pre-dated the legal recognition of their right to form such unions. In reviewing these existing doctrines, it is important to note how the courts resort to them primarily for reasons of equity, focusing on the need to protect parties from the harms they would otherwise suffer were the court to rigidly insist on form over substance.

\section{A. Informal Marriage}

Common law marriage provides likely the most obvious example of legally recognized family relationships that arise through informal means. Also referred to as informal marriage, common law marriage "is formed by the conduct, statements, and intent of the parties to the marriage without official involvement or formalities." 188 However, unlike the other equitable remedies discussed below where parties can claim some of the rights associated with either marriage or parentage, common law marriage results in a legal union that carries with it the same rights and obligations of formal

${ }^{186}$ Michael J. Higdon, The Quasi-Parent Conundrum, 90 U. CoLO. L. REV. 941, 948-49 (2019) (discussing various social changes that have led to American families being "more heterogeneous than ever before").

187 Supriya Kakkar, Unauthorized Embryo Transfer at the University of California, Irvine Center for Reproductive Health, 24 Hastings ConsT. L.Q. 1015, 1031 (1997); see also Bradley G. Silverman, Federal Questions and the Domestic-Relations Exception, 125 YALE L.J. 1364, 1392 (2016) ("Crafting a workable system of family law requires calibrating a complex level of benefits to which state law entitles those who occupy different familial roles.") (internal quotes omitted).

${ }^{188}$ Rhodes, supra note 17, at 437. 
marriage. ${ }^{189}$ As Judge Posner explained in a 2000 opinion from the Seventh Circuit: "The purpose of common law marriage is not to create a second-class sort of marriage, but rather to repair unintended deficiencies in the ceremony. [and thus] a common law spouse has the same rights as any other spouse."190

Despite the implications of its name, common law marriage is largely an American invention. ${ }^{191}$ An 1809 case out of New York is commonly credited as the first to recognize the legality of informal marriage, ${ }^{192}$ and the facts of that case help explain why states would embrace having this alternative path to legal marriage. In Fenton v. Reed, Mrs. William Reed claimed a widow's pension from the Provident Society after the 1806 death of her husband. ${ }^{193}$ The Society refused, however, on the basis that her marriage to William was invalid. ${ }^{194}$ After all, William was not her first husband. Instead, she had previously wed a man named John Guest, who in 1785 left her and traveled to "foreign parts." 195 When he did not return, she married Reed in 1792, believing her first husband to be dead. ${ }^{196}$ Guest was not dead, however, and returned to New York later that year, where he lived until his death in $1800^{197}$.

During this time, Guest "did not object to the connection between the plaintiff and Reed, and said that he had no claim upon her, and never interfered to disturb the harmony between them."198 Nonetheless, given that she never divorced her first husband and he was still living when she married Reed, the Society argued that her second marriage was void. ${ }^{199} \mathrm{Had}$ she attempted to marry Reed again following Guest's death, the marriage would

189 See Peter Nicolas, Common Law Same-Sex Marriage, 43 ConN. L. REV. 931, 934 (2011) ("When entered into, a common law marriage provides the same rights, privileges, and responsibilities as a ceremonial marriage, and is as durable as a ceremonial marriage, requiring divorce proceedings to terminate the relationship.").

${ }^{190}$ Barron v. Apfel, 209 F.3d 984, 985 (7th Cir. 2000).

191 See Lawrence M. Friedman, A History OF AmErican Law 202-04 (2d ed. 1985) ("Probably there was no such institution [as common law marriage] in England."); Adair Dyer, The Internationalization of Family Law, 30 U.C. DAVIS L. REV. 625, 626 (1997) (noting that 'the informal contractual status known as 'common law marriage' may have been an American innovation").

192 See Charles P. Kindregan, Jr., Same-Sex Marriage: The Cultural Wars and the Lessons of Legal History, 38 FAM. L.Q. 427, 434 n. 45 (2004) (“Informal marriage appears to have first been recognized by the New York court in Fenton v. Reed.").

${ }^{193}$ Fenton v. Reed, 4 Johns. 52 (1809).

194 Id. at 52-53.

195 Id. at 52.

${ }^{196} I d$. ("[I]t was reported, and generally believed, that [Guest] had died in foreign parts.").

${ }^{197} I d$

${ }^{198} I d$.

${ }^{199}$ Id. at 53. In part, the court agreed: "The marriage of the plaintiff below with William Reed during the life-time of her husband John Guest, was null and void.” Id. 
have been valid, but she did not "re-solemnize" her relationship with Reed. ${ }^{200}$ The court, however, disagreed and held that it was not necessary to prove that the marriage had been solemnized. Instead, "[a] marriage may be proved ... from cohabitation, reputation, acknowledgment of the parties, reception in the family, and other circumstances from which a marriage may be inferred." 201 Turning to the facts of the case, the court found that circumstances were such that, although her attempt to formally marry Reed was invalid given her existing marriage to Guest, she subsequently effectuated a common law marriage with Reed after her first husband died: "The parties cohabited together as husband and wife, and under the reputation and understanding that they were such, from 1800 [when Guest died] to 1806, when Reed died."202

Other states would soon embrace the doctrine and its ability to protect the interests of those in economically dependent relationships. ${ }^{203}$ By the end of the nineteenth century, common law marriage would become the law in a majority of the states. ${ }^{204}$ It proved popular for a number of reasons, including how well-suited it was to frontier conditions where finding someone to perform a formal wedding might be difficult, ${ }^{205}$ how it provided individuals with greater autonomy and freedom from the state; ${ }^{206}$ how it helped legitimize children; ${ }^{207}$ and how it provided for unsuspecting women who

${ }^{200} I d$. at 52 (" $[\mathrm{N}]$ o solemnization of marriage was proved to have taken place between the plaintiff and Reed, subsequent to the death of Guest.").

${ }^{201} I d$. at 54 ("No formal solemnization of marriage was requisite. A contract of marriage made per verba de presenti amounts to an actual marriage.").

${ }^{202} I d$.

203 See Judith T. Younger, Marital Regimes: A Story of Compromise and Demoralization, Together with Criticism and Suggestions for Reform, 67 CORNELL L. REV. 45, 65-66 (1981) ("The idea that marriage could be validated by the mere consent of the spouses gained strength from cases that ... recognized informal or 'common law' marriages and appeared in community property as well as in common law states.").

204 See Cynthia Grant Bowman, A Feminist Proposal to Bring Back Common Law Marriage, 75 OR. L. REV. 709, 715 (1996) (noting that the doctrine was recognized by "a majority of the states in 1920 and even more in the nineteenth century").

205 See Perry Dane, A Holy Secular Institution, 58 EMORY L.J. 1123, 1147 (2009) (identifying as one of the reasons states embraced common law marriage, "the difficulty of requiring resort to either a governmental or religious official in a dispersed frontier society").

206 See Nicolas, supra note 189, at 939 ("One oft-cited rationale [for common law marriage] is a libertarian concept of autonomy and independence, the idea that marriage is a natural right and that individuals should be free to enter into marriages without the need to invoke the power of the state.").

${ }^{207}$ See Kristin A. Collins, Illegitimate Borders: Jus Sanguinis Citizenship and the Legal Construction of Family, Race, and Nation, 123 YALE L.J. 2134, 2166 (2014) ("Judges and lawyers acknowledged that a primary purpose of common law marriage was to ensure that children born of such a union were legitimate."). 
relied to their detriment on the existence of a valid marriage. ${ }^{208}$ In 1877 , the Supreme Court seemingly gave its blessing to the idea of marriage by informal means when it held that, unless a state explicitly required formal marriage, marriage laws that required a license and a ceremony were "merely directory." 209

As the United States entered into the twentieth century, however, common law marriage would begin to lose favor rather rapidly. ${ }^{210}$ The various reasons for that decline have been well-documented elsewhere and thus do not require expansive discussion here, but in the words of Professor Cynthia Grant Bowman, it essentially boiled down to "urbanization, industrialization, concerns about fraud, the ideology of the family, racism, and eugenics."211 Currently, only eight states and the District of Columbia allow their citizens to effectuate marriage through informal means. ${ }^{212}$ Even those states, however, require heightened proof in order to establish a common law marriage, ${ }^{213}$ the most central being that the two parties have "an express mutual agreement, which must be in words of the present tense." 214 Recognizing that, in the absence of a formal ceremony, it might be difficult to prove the existence of such an agreement, many states permit parties to prove the agreement by relying on evidence of cohabitation and having a reputation in the community as being marriedt. ${ }^{215}$ Other states explicitly

208 See Ariela R. Dubler, Wifely Behavior: A Legal History of Acting Married, 100 COLUM. L. REV. 957, 964 (2000) ("As common law marriage triumphed as a dominant legal rule over the course of the nineteenth century, it took as its premise that the law should protect innocent women from the whims and contrivances of irresponsible or rakish men.").

${ }^{209}$ Meister v. Moore, 96 U.S. 76, 78 (1877).

210 See Ashley Hedgecock, Untying the Knot: The Propriety of South Carolina's Recognition of Common Law Marriage, 58 S.C. L. REV. 555, 562 (2007) ("Beginning in the late nineteenth century, many jurisdictions that previously recognized common law marriage began to abolish the doctrine.").

${ }^{211}$ Bowman, supra note 204, at 732.

212 See Common Law Marriage By State, Nat'l Conf. Of State Legislatures (March 11, 2020), available at http://www.ncsl.org/research/human-services/common-lawmarriage.aspx (listing states). However, the Supreme Court of South Carolina recently ruled that, going forward, it will no longer allow its citizens to enter into common law marriages although it will continue to those that couples effectuated in the past. See Stone v. Thompson, 833 S.E.2d 266 (S.C. 2019).

213 See Michael J. Higdon, Fatherhood by Conscription: Nonconsensual Insemination and the Duty of Child Support, 46 GA. L. REV. 407, 453 (2012) ("[C]ourts in those states recognizing common law marriage have noted that such claims are a 'fruitful source of perjury and fraud' and, as such, have placed a heavy burden on the party claiming common law marriage.”) (quoting Staudenmayer v. Staudenmayer, 714 A.2d 1016, 1019 (Pa. 1998)).

${ }^{214}$ Cerovic v. Stojkov, 134 A.3d 766, 777 (D.C. 2016).

215 See Ellen Kandoian, Cohabitation, Common Law Marriage, and the Possibility of A Shared Moral Life, 75 GEO. L.J. 1829, 1842-43 (1987) ("Although the doctrine of common law marriage purportedly depends on the existence of an agreement to be married, normally an agreement is inferred by courts when a couple engages in cohabitation and acquires a 
require the parties to prove cohabitation and reputation along with the existence of the agreement to enter into a common law marriage. ${ }^{216}$ States also require that the parties had the capacity to wed one another. ${ }^{217}$

Although most states do not permit people within the state to effectuate a common law marriage, under full-faith and credit, all will recognize a common-law marriage validly effectuated in a state to does permit such unions. $^{218}$ States do so pursuant to the lex loci rule by which "courts will give effect to laws and judicial decisions of another state or jurisdiction, not as a matter of obligation but out of deference and respect." ${ }^{219}$ Thus, even states that do not permit common law marriage can nonetheless use that doctrine to extend family law protections to citizens who spent time in a state that does permit informal marriage. Many states have done just that, often by liberally construing the common law marriage requirements of a sister state. ${ }^{220}$ In reviewing such cases, it is clear that the court did so in order to protect economically dependent "spouses" from the harms that would result from a finding that there was never a valid marriage.

The classic example of a court doing just that is Renshaw v. Heckler, a 1986 case out of the Second Circuit. ${ }^{221}$ There, Edith Renshaw claimed to be the common-law wife of Albert Renshaw for purposes of securing Social Security benefits following Albert's death. ${ }^{222}$ The couple were never formally

reputation as husband and wife.").

${ }^{216}$ Lawrence W. Waggoner, Marital Property Rights in Transition, 59 Mo. L. REV. 21, 74 n.132 (1994) ("Most jurisdictions also require cohabitation, or actually and openly living together as husband and wife.... Some jurisdictions further require that the parties hold themselves out to the world as husband and wife, and acquire a reputation as a married couple.").

217 See Strasser, supra note 17, at 414 (“A couple barred by law from celebrating a ceremonial marriage will also be barred from contracting a common law marriage."). In terms of how that term is defined, Peter Nicolas explains that capacity "is interpreted to refer to minimum age and mental capacity [but also] encompasses any potential legal impediment to marrying, such as whether the parties are already married to other people, whether the marriage would be incestuous, or whether the parties to the relationship are of the same sex." Nicolas, supra note 17, at 418 n.136.

218 See Lisa Milot, Restitching the American Marital Quilt: Untangling Marriage from the Nuclear Family, 87 VA. L. REV. 701, 707-08 (2001) ("[B]ecause of the full faith *708 and credit afforded a valid marriage in one state by other states, though, all states recognize the legal legitimacy of a common-law marriage contracted in another jurisdiction.").

219 Port v. Cowan, 426 Md. 435, 444, 44 A.3d 970, 975 (2012).

220 See Adam Candeub \& Mae Kuykendall, Modernizing Marriage, 44 U. MiCH. J.L. REFORM 735, 759 (2011) ("[C]ourts in states that do not recognize common law marriage sometimes stretch doctrine to recognize common law marriages of couples who reside there.").

${ }^{221}$ Renshaw v. Heckler, 787 F.2d 50 (2d Cir. 1986)

222 Id. at 51 . 
married but had been living as though they were for over twenty years. ${ }^{223}$ They exchanged rings, celebrated their anniversary every year, and represented themselves as married to those around them. ${ }^{224}$ The two even had a child together. ${ }^{225}$ The problem, however, was that they resided in New York, which no longer permitted common law marriage. Nonetheless, the court found that the two had effectuated a common law marriage.

It did so by relying on the fact that, for seven years in a row, the two took an annual road trip to Virginia and North Carolina 226 - two states that likewise do not permit common law marriage. Pennsylvania, however, did allow informal marriage and that fact proved relevant because the couple spent a single night in Pennsylvania during each of these trips. ${ }^{27}$ Like other common law states, Pennsylvania looked to cohabitation and reputation when determining whether a couple had effectuated a common law marriage. ${ }^{228}$ The Renshaws had clearly satisfied those elements over the course of their long-term relationship, but the question was whether they had done so while in Pennsylvania. 229 Despite noting that Pennsylvania places a "heavy burden" 230 on those seeking to establish a common law marriage, the court nonetheless found that Edith had met that standard:

The Renshaws' stays in Pennsylvania were admittedly short; but they cohabitated during the entire time that they were there. While the evidence of reputation is not extensive, they held themselves out as husband and wife to every individual they knew that they saw in Pennsylvania-his mother, her brother, and their daughter. Moreover, Mrs. Renshaw testified that when Mr. Renshaw made reservations over the phone, he indicated on at least one occasion that the

${ }^{223} \mathrm{Id}$.

${ }^{224} I d$. Additionally, she took his last name and "the couple filed joint tax returns as husband and wife, and Mr. Renshaw listed Mrs. Renshaw as his wife and beneficiary on his life insurance policy." Id.

${ }^{225} \mathrm{Id}$.

${ }^{226} I d$. at $51-52$.

${ }^{227} \mathrm{Id}$. at 52.

${ }^{228} I d$. ("Generally, a common-law marriage may be created by uttering words in the present tense with the intent to establish a marital relationship, but where no such utterance is proved, Pennsylvania law also permits a finding of marriage based on reputation and cohabitation when established by satisfactory proof.") (citing In re Estate of Wagner, 159 A.2d 495, 498 (Pa. 1960). (internal cites omitted).

${ }^{229}$ Id. It was on this basis that the lower court had ruled against Ms. Renshaw finding that "at best only 16 days out of Mr. Renshaw's lifetime were spent in Pennsylvania [and] the overwhelming bulk of the supporting evidence rests on actions taken outside of Pennsylvania in non-common law states." Id.

${ }^{230} I d$. at 52. 
reservations were for himself, his wife, and their daughter. ${ }^{231}$

Although the court stated that, "in different circumstances, such facts alone might not prove sufficient," 232 it nonetheless held that "the Renshaws' conduct while in Pennsylvania and elsewhere is similarly sufficient to . . . conclude that the Renshaws entered into a valid common-law marriage under Pennsylvania law."233

Renshaw is but one example where a court has held that a valid common law marriage arose after only a few days in a common law marriage state..$^{234}$ Although the reasoning in these cases appears to be a bit of a stretch, ${ }^{235}$ the states are clearly motivated to protect the economic interests of vulnerable citizens. $^{236}$

\section{B. Invalid Marriage}

Whereas common law marriage allows parties to effectuate a marriage through informal means, other doctrines in the law allow a party to collect marital benefits from a formal marriage that was nonetheless invalid. Collectively, these doctrines are often referred to as the marriage validation principle, which courts use to try and find a valid marriage even in the face of facts that cast enormous doubt on that conclusion. ${ }^{237}$ The courts take this approach in light of the harms that could befall an economically dependent "spouse" who ultimately discovers that her marriage is invalid, thus depriving her of the benefits and protections to which she thought she was entitled. ${ }^{238}$

${ }^{231} I d$. at 53.

${ }^{232} \mathrm{Id}$.

${ }^{233} I d$. at 54.

234 See, e.g., Blaw-Knox Constr. Equip. Co. v. Morris, 596 A.2d 679 (Md. Ct. Spec. App. 1991) (holding that Maryland couple effectuated a common law marriage after spending two nights at a Pennsylvania hotel to attend a funeral); In Re Claim of Coney v. R.S.R. Corp., 563 N.Y.S.2d 211 (App. Div. 1990) (holding that couple effectuated a common law marriage after spending three days traveling through Georgia).

${ }^{235}$ See Adam Candeub \& Mae Kuykendall, Modernizing Marriage, 44 U. MicH. J.L. REFORM 735, 759 (2011) (noting that "courts in states that do not recognize common law marriage sometimes stretch doctrine to recognize common law marriages of couples who reside there").

${ }^{236}$ See Pamela Laufer-Ukeles \& Ayelet Blecher-Prigat, Between Function and Form: Towards A Differentiated Model of Functional Parenthood, 20 GeO. MASON L. REv. 419, 453 (2013) (pointing out that, because "traditional common law marriage is not likely to make a modern comeback. . . alternative constructs and regulations are used to protect vulnerable parties in long-term cohabitant relationships").

${ }^{237}$ See EsTIN, supra note 118, at 98 ("[T] he marriage validation principle . . . seeks to uphold marriages whenever possible.").

238 See Lynn D. Wardle, Deconstructing Family: A Critique of the American Law Institute's "Domestic Partners" Proposal, 2001 B.Y.U. L. ReV. 1189, 1198 (2001) ("The 
Two notable examples of ways in which courts attempt to validate questionable marriages are the doctrines of marriage by estoppel and putative marriage.

Marriage by estoppel prohibits a party from using an invalid divorce in order to void a subsequent marriage. However, the doctine "is unlike classic equitable estoppel in that it does not focus solely on whether one party has made a misrepresentation on which the other has reasonably relied." 239 Instead, "[t]he focus is broader and requires a consideration of all of the circumstances surrounding not only the procurement of the divorce, but also the conduct of the parties thereafter and the effect of a declaration of the invalidity of the divorce on others." ${ }^{440}$ As such, "[i]t is sufficient, in many cases, that a court find only that it would be unfair to let a party take advantage of the legal invalidity of a divorce decree and the invalidity of the subsequent marriage." 241

Consider the case of Lowenschuss v. Lowenschuss, where Pennsylvania resident Beverly Lowenschuss divorced her first husband in 1964 after traveling to Alabama. ${ }^{242}$ However, because she failed to establish residency in Alabama, her divorce was invalid. ${ }^{243}$ Not realizing her failure, Beverly returned to Pennsylvania, where she met and married Fred Lowenschuss. ${ }^{244}$ The couple eventually had four children together. ${ }^{245}$ Although Fred testified that he learned of Beverly's defective divorce in 1974, he nonetheless remained in the relationship as though nothing had changed. ${ }^{246}$ In 1981, Beverly filed for divorce. ${ }^{247}$ In response, Fred argued that, because she never legally divorced her first husband, he and Beverly were never legally married. ${ }^{248}$ The court, however, held that Fred was estopped from raising the

goal of protecting the financial interests or financial equity of individuals who enter into such relationships is similar to the policy underlying common law marriage, putative spouse, and equitable doctrines.").

${ }^{239}$ Lowenschuss v. Lowenschuss, 579 A.2d 377, 381 (Pa. Super. Ct. 1990).

${ }^{240} I d$.

241 John De Witt Gregory, Peter N. Swisher \& Robin Fretwell Wilson, UNDERSTANDING FAMILY LAW 39 (2013)

${ }^{242} I d$. at 378 . Around this time, Alabama was a popular destination for those seeking a relatively easy and quick divorce. See generally, Migratory Divorce: The Alabama Experience, 75 HARV. L. REV. 568, 569 (1962)

${ }^{243}$ Id. ("Wife spent at most two days in Alabama and does not dispute the fact that she has never been a bona fide resident of Alabama.").

${ }^{244}$ Fred was an attorney and he "knew that wife was divorced, but denies knowing any of the details concerning how the divorce was procured." 579 A.2d at 534.

${ }^{245} \mathrm{Id}$. at 535 .

${ }^{246} \mathrm{He}$ learned of the divorce that year after he commenced a divorce action, which he subsequently withdrew. Id.

${ }^{247} I d$. at 377.

${ }^{248} I d$. 
circumstances of Beverly's previous divorce.

Even though Fred was not a party to her prior divorce proceedings, the court ruled that, in light of his conduct, it would be inequitable for him to raise that defense at this late date. ${ }^{249}$ Both parties "relied in good faith on the Alabama divorce in marrying each other in 1965 and continued to rely on that divorce at minimum until $1974 \ldots$. . Husband conducted himself as a married man for nine years before 1974 and after 1974 he continued to live as he had before." ${ }^{250}$ Ultimately, the court found that:

[n]o social purpose will be served by a decision that this marriage simply does not exist and that wife is still the legal wife of her first husband and that her four children were born of an illicit relationship. To hold that husband may now raise this challenge simply in order to avoid the financial obligations of his marriage would be grossly inequitable. ${ }^{251}$

To justify its ruling, the court reiterated the important and protective function of both marriage and divorce, writing that "a decision which would allow husband to avoid his marital obligations at this late juncture would be completely inconsistent with the Commonwealth's contemporary attitude toward divorce, which is grounded in the application of equitable principles to achieve economic justice and overall fairness between the parties." ${ }^{252}$ As the court's opinion makes clear, Fred was estopped largely because he continued in the marriage long after her learned of the faulty divorce. Had he sought to invalidate the marriage shortly after learning the truth, he would have had a stronger argument. However, Beverly might have still had some recourse as a putative spouse.

Putative marriage is another marriage validation principle, and it allows courts to extend the civil effects of marriage to one who in good faith entered into a marriage that was nonetheless invalid. In other words, "[a] putative marriage ... is a marriage which is in reality null, but which allows the civil effects of a valid marriage to flow to the party or parties who contracted it in good faith." 253 The only requirements parties must meet to avail themselves of this protection is to have had a ceremonial marriage and to have done so

${ }^{249} I d$. at 549 ("Such a decision would contravene the strongly entrenched policy of this Commonwealth favoring preservation of the family unit.").

${ }^{250} I d$. at $548-49$.

${ }^{251} \mathrm{Id}$. at 549. ("Therefore, we hold that principles of estoppel based on well-established social policies favoring preservation of the family and economic justice require us to estop husband from asserting the invalidity of wife's Alabama divorce.").

${ }^{252} I d$. at 550.

${ }^{253}$ See Christopher L. Blakesley, The Putative Marriage Doctrine, 60 TuL. L. Rev. 1, 6 (1985). 
with a good faith belief that the marriage was valid ${ }^{254}$ - good faith being defined as "an honest and reasonable belief that there exists no legal impediment to the marriage." 255

Although putative marriage does not equal legal marriage, ${ }^{256}$ the doctrine is nonetheless intended to promote equity and to protect innocent spousesfor example, individuals who innocently but erroneously believed that they had obtained a valid divorce prior to remarrying. As one court explained, "a marriage contracted when one spouse is a party to a previously undissolved marriage is absolutely null; however, equity demands that innocent persons not be injured through an innocent relationship." ${ }^{257}$ As Professor Christopher Blakesley points out, the primary motivation behind this doctrine is the desire to ensure fairness. "The putative marriage doctrine is a device developed to ameliorate or correct the injustice which would occur if civil effects were not allowed to flow to a party to a null marriage who believes in good faith that he or she is validly married." 258

To illustrate, consider the 2004 Nevada case of Williams v. Williams. There, Richard and Marcie Williams were married in 1973 and lived together as husband and wife for the next twenty-seven years, at which time Richard learned that Marcie had never divorced her first husband. ${ }^{259}$ As a result, Richard filed an annulment action to have his marriage to Marcie declared void. $^{260}$ The Supreme Court of Nevada used this opportunity to adopt the putative spouse doctrine so as to ensure "[f]airness and equity." 261 The court ruled that a putative marriage existed. It did so even in the face of Richard's argument that Marcie had not entered into their marriage in good faith. Specifically, Marcie testified "that in 1971, she ran into [her first husband] at

254 See Katherine Shaw Spaht, Revision of the Law of Marriage: One Baby Step Forward, 48 LA. L. REV. 1131, 1150 (1988) ("A prerequisite to the application of the putative marriage doctrine is contracting the marriage in good faith. The word contracting suggests a ceremony, which would mean that a marriage that is absolutely null because of no ceremony 130 would never produce civil effects.").

255 Casey E. Faucon, "Living Separate and Apart": Solving the Problem of Putative Community Property in Louisiana, 85 TuL. L. REV. 771, 774 n.11 (2011); see also Succession of Marinoni, 164 So. 797, 804 (La. 1935) (defining good faith as "ignoran[ce] of the cause which prevents the formation of the marriage or the defects in its celebration which caused its nullity"').

${ }^{256}$ See Lee v. Hunt, 431 F. Supp. 371, 376 (W.D. La. 1977) (“[A] 'putative spouse' is not a spouse and has no personal status. Instead, a 'putative marriage' merely creates the responsibilities that one spouse owes the other because one spouse is guilty of a fault and the other innocently believes the marriage is genuine.").

${ }^{257}$ Lee v. Hunt, 483 F. Supp. 826, 842 (W.D. La. 1978).

${ }^{258}$ Blakesly, supra note 253, at 6.

${ }^{259}$ Williams v. Williams, 97 P.3d 1124, 1126 (Nev. 2004) (per curiam).

${ }^{260} \mathrm{Id}$. ("Marcie answered and counterclaimed for one-half of the property and spousal support as a putative spouse.").

${ }^{261} I d$. at 1128. 
a Reno bus station, where he specifically told her that they were divorced and he was living with another woman." 262 Richard argued that such reliance was unreasonable given that she had never been served with divorce papers, and, at the very least, she had a duty to inquire further into the existence of the "divorce" before marrying again. ${ }^{263}$ The court, however, rejected Richard's arguments and held that "[t]he record reflects no reason for Marcie to have disbelieved him and, thus, no reason to have investigated the truth of his representations." 264

In ruling as it did, the court took extensive note of Marcie's financial circumstances:

During the 27 years that the parties believed themselves to be married, Marcie was a homemaker and a mother. From 1981 to 1999, Marcie was a licensed child-care provider for six children. During that time, she earned $\$ 460$ a week. At trial, Marcie had a certificate of General Educational Development (G.E.D.) and earned $\$ 8.50$ an hour at a retirement home. She was 63 years old and lived with her daughter because she could not afford to live on her own. ${ }^{265}$

Implicit in this recitation is the court's awareness of the degree to which Marcie would be harmed if forced to walk away from a twenty-seven-year relationship, which she believed was a marriage, with no rights to the "marital" property. By finding that Marcie was - if not a legal spouse-a putative spouse, the property acquired during her marriage to Richard was labeled quasi-community property and divided equally between them.

\section{No Marriage}

Some states have even used their equitable powers to award marital benefits to individuals who never married, but merely cohabitated in a domestic relationship. Historically, the states did very little to protect the economic interests of those who enter into such relationships. ${ }^{266}$ And they did

${ }^{262}$ Id. at 1127 ("According to Marcie, she discovered she was still married to [Richard] during the course of the annulment proceedings with Richard.")

263 Id. at 1129.

${ }^{264} \mathrm{Id}$. Relatedly, the court also ruled that "[g]ood faith is presumed. The party asserting lack of good faith has the burden of proving bad faith." Id. at 1128.

265 Id. at 1127.

266 See Margaret M. Mahoney, Forces Shaping the Law of Cohabitation for Opposite Sex Couples, 7 J. L. \& FAM. STUD. 135, 159 (2005) ("[H]istorically, the cohabiting relationship was treated as a 'negative status' in the law. That is, unmarried cohabitants experienced significant legal burdens by virtue of their relationship alone.”). 
so purposefully, reasoning that any benefits afforded cohabitating couples might discourage formal marriage. ${ }^{267}$ With its landmark decision in Marvin v. Marvin, ${ }^{268}$ however, California began to change all that, holding that express contracts between cohabitants regarding property distribution were enforceable so long as they were not conditioned "upon the immoral and illicit consideration of meretricious sexual services." 269 In the absence of an express agreement, the Supreme Court of California held that recovery was likewise permitted on the basis of implied contract "or equitable remedies such as constructive or resulting trusts." 270

By opening the door to legal protections for cohabitants, Marvin was heavily criticized by those who feared that such an approach would "weaken marriage as the foundation of our family-based society." ${ }^{271}$ However, in the more than forty years that have elapsed since Marvin was issued, most agree that overall it had little impact. ${ }^{272}$ First, a handful of states continue in their refusal to enforce any cohabitation agreements. ${ }^{273}$ Second, even among those that do, Marvin and its progeny only offer limited protections. Specifically, state law protections for cohabitants typically require that the parties entered into an agreement regarding their respective rights. ${ }^{274}$ While some states permit implied agreements, others require that they be express. ${ }^{275}$ Some states

${ }^{267}$ See Emily Sherwin, Love, Money, and Justice: Restitution Between Cohabitants, 77 U. Colo. L. REV. 711, 722 (2006) (noting the concern that providing "legal equivalence between marriage and cohabitation will devalue and discourage marriage").

${ }^{268}$ Marvin v. Marvin, 557 P.2d 106 (Cal.1976) (en banc).

${ }^{269} \mathrm{Id}$. at 112 .

${ }^{270} I d$. at 110 .

${ }^{271}$ Hewitt v. Hewitt, 394 N.E.2d 1204, 1207, 1211 (Ill. 1979) (holding that cohabitation agreements "are unenforceable for the reason that they contravene the public policy [of the state] disfavoring the grant of mutually enforceable property rights to knowingly unmarried cohabitants").

272 As Deborah Rhode has pointed out, "what little empirical evidence is available suggests that cohabitation generally is not the result of a conscious choice. Rather, individuals tend to drift into such relationships without focusing on the future or its legal implications.” Deborah L. Rhode, Justice and Gender: Sex Discrimination and the LAW 138 (2009).

${ }^{273}$ Deborah Zalesne, The Contractual Family: The Role of the Market in Shaping Family Formations and Rights, 36 CARDOZO L. REv. 1027, 1039 (2015) ("[E]ven today, Illinois, Georgia, and Louisiana still do not recognize cohabitation contracts between either oppositesex or same-sex couples.").

274 See Elizabeth S. Scott, Marriage, Cohabitation and Collective Responsibility for Dependency, 2004 U. CHI. Legal F. 225, 262 (2004) (describing the "contract-based" approach as the "default framework").

${ }^{275}$ See, e.g., Morone v. Morone, 413 N.E.2d 1154, 1158 (N.Y. 1980) ("The notion of an implied contract between an unmarried couple living together is, thus, contrary to both New York decisional law and the implication arising from our Legislature's abolition of commonlaw marriage."). 
even insist that the agreements be in writing. ${ }^{276}$ Regardless, by conditioning legal protection on the existence of a contract, relatively few cohabitants are likely to benefit given that, as one commentator aptly notes, "[i]f couples do not think of their relationship in contract terms, then a doctrine that directs courts to decide their disputes by looking for a contract is unlikely to find one." 277

Nonetheless, two states that do offer protections for cohabitants whose relationship has ended do so by analogizing to the states' divorce laws. For example, the Supreme Court of Nevada has held that property that cohabitants agreed to hold "as if they were married" is subject to the state's community property laws. ${ }^{278}$ In so ruling, the court emphasized that it "by no means seeks to encourage, nor does this opinion suggest, that couples should avoid marriage." 279 Instead, the court "reaffirm[ed] this state's strong public policy interest in encouraging legally consummated marriages." 280 Nonetheless, the court pointed out that "this policy is not furthered by allowing one participant . . . to abscond with the bulk of the couple's acquisitions." 281

Washington has gone one step further and eschews the contract approach altogether, focusing instead on the existence of a "a stable, marital-like relationship." 282 For cohabitants who establish the existence of such a relationship (sometimes referred to as the "meretricious relationship test"283), the Supreme Court of Washington has held that "income and property acquired during [the relationship] should be characterized in a similar manner as income and property acquired during marriage." 284 Washington courts have even applied this approach to same-sex cohabitants, giving them marriage-like remedies years before the state would permit same-sex marriage. Consider, for instance, a 2004 case in which Lynn Gormley and Julia Robertson were involved in a ten-year relationship. ${ }^{285}$ After examining

276 See Patricia A. Cain, Taxing Families Fairly, 48 SANTA ClarA L. REV. 805, 832 n.103 (2008) ("At least three states require a written contract when the consideration is nonmarital conjugal cohabitation.").

${ }^{277}$ Ira Mark Ellman, "Contract Thinking" Was Marvin's Fatal Flaw, 76 Notre Dame L. REV. 1365, 1368 (2001).

${ }^{278}$ W. States Const., Inc. v. Michoff, 840 P.2d 1220, 1222 (Nev. 1992).

${ }^{279} \mathrm{Id}$. at 1223 .

${ }^{280} \mathrm{Id}$.

${ }^{281} I d$. at $1223-24$.

${ }^{282}$ See Connell v. Francisco, 898 P.2d 831, 834 (Wash. 1995) (en banc) ("A meretricious relationship is a stable, marital-like relationship where both parties cohabit with knowledge that a lawful marriage between them does not exist.").

${ }^{283}$ See generally Gavin M. Parr, What Is A "Meretricious Relationship"?: An Analysis of Cohabitant Property Rights Under Connell v. Francisco, 74 WASH. L. REV. 1243 (1999)

${ }^{284}$ Connell, 898 P.2d at 836.

${ }^{285}$ Gormley v. Robertson, 83 P.3d 1042, 1043 (Wash. Ct. App. 2004). 
the nature of the couple's relationship, the court ruled that they were entitled to an equitable division of property. ${ }^{286}$

In so ruling, the court rejected the argument that, because the two women could not legally marry, their relationship could not be construed as "quasimarital": "it is of no consequence to the cohabitating couple, same-sex or otherwise, whether they can legally marry. Indeed, one of the key elements of a meretricious relationship is knowledge by the partners that a lawful marriage between them does not exist." 287 While agreeing that "[w]hether same-sex couples can legally marry is for the legislature to decide," the court concluded that the duty to "examine the [meretricious] relationship and the property accumulations and make a just and equitable disposition of the property" is a judicial, not a legislative, extension of the rights and protections of marriage to intimate, unmarried cohabitants." 288

\section{Informal Adoption}

States have not only relied on informal acts to award marital benefits, they also permit informal acts to justify recognition of certain parent-child relationships. One such example is the doctrine of equitable adoption. Also referred to as "virtual adoption," "de facto adoption," and "adoption by estoppel," 289 equitable adoption is designed to protect individuals who mistakenly believe themselves to be the legal child (whether biological or through adoption) of another. ${ }^{290}$ The doctrine, which has been recognized in a majority of the states, ${ }^{291}$ typically arises in the context of "parental" disinheritance; however, courts have also relied on the doctrine in other areas

${ }^{286} I d$. at 1044 ("They pooled their resources and acquired property as well as debt. They had a joint banking account that was used to pay all monthly obligations, whether preexisting or incurred separately or jointly.").

${ }^{287}$ Id. at 1045.

288 Id. at 1046.

289 See Michael J. Higdon, When Informal Adoption Meets Intestate Succession: The Cultural Myopia of the Equitable Adoption Doctrine, 43 WAKE FOREST L. REV. 223, 225 (2008).

290 See Lindsay Ayn Warner, Bending the Bow of Equity: Three Ways Florida Can Improve Its Equitable Adoption Policy, 38 StETSON L. REV. 577, 585 (2009) ("Equitable adoption protect[s] the interests of a minor child who, through no fault of his or her own, was never formally and legally adopted by his or her adoptive parents.") (internal quotes omitted).

${ }^{291}$ See Kristine S. Knaplund, Grandparents Raising Grandchildren and the Implications for Inheritance, 48 ARIZ. L. REV. 1, 6 (2006) ("Since at least twenty-eight states do recognize equitable adoption, the doctrine remains a theoretical option in a majority of states."). 
as well, including divorce proceedings ${ }^{292}$ and claims of parental rights. ${ }^{293}$ Historically, equitable adoption has been "predicated on principles of contract law and equitable enforcement of the agreement to adopt," ${ }^{294}$ and thus courts have typically required the existence of an adoption contract before permitting a party to pursue a claim for equitable adoption. ${ }^{295}$

Requiring the existence of a contract, however, can work great injustice. The case of O'Neal $v$. Wilkes provides an excellent example. ${ }^{296}$ There, Hattie O'Neal was an African American child born in 1949 to an unwed mother, who died when Hattie was only eight years old. ${ }^{297}$ Hattie was eventually sent to Georgia to live with an aunt, who in turn placed Hattie with a married couple, Mr. and Mrs. Roswell Cook, that were looking to adopt a little girl. ${ }^{298}$ Although the Cooks never formally adopted Hattie, from the time she went home with the Cooks until she married in 1975, she was in all meaningful ways their "daughter." ${ }^{299}$ After Hattie left their home and got married, she continued her relationship with the Cooks, who referred to Hattie's children as their "grandchildren." 300 When Mr. Cook died without a will, Hattie brought suit, claiming that Cook had adopted her by way of a "virtual adoption" and, as such, was entitled to inherit from him. ${ }^{301}$ The Supreme Court of Georgia refused Hattie's claim for the sole reason that her aunt did not have the legal authority to enter into an adoption contract with the Cooks. ${ }^{302}$

Recognizing the unfairness that can arise from such a rigid requirement, a number of states have instead started to rely "on equitable principles of

${ }^{292}$ See, e.g., Johnson v. Johnson, 617 N.W.2d 97, 109 (N.D. 2000) ("The substantive circumstances of this case, a divorce in which child support was requested, are identical to the other cases in which husbands have been held to have equitably adopted children for the purposes of imposing child support.").

${ }^{293}$ See, e.g., Nguyen v. Boynes, 396 P.3d 774, 779 (Nev. 2017) (concluding "that the district court did not err in granting Rob paternity through equitable adoption of the child").

${ }^{294}$ Lankford v. Wright, 489 S.E.2d 604, 606 (N.C. 1997) (quoting 2 Am.Jur.2d Adoption $\S 53$ (1994)).

295 See Higdon, supra note 289, at 225 ("[T] the tests that courts have developed to determine whether an equitable adoption exists almost invariably require that there first have been a contract to adopt between the natural and 'foster' parents.").

${ }^{296}$ O'Neal v. Wilkes, 439 S.E.2d 490 (Ga. 1994).

${ }^{297}$ Id. at 851 .

${ }^{298} I d$.

${ }^{299}$ Id. ("Although O'Neal was never statutorily adopted by Cook, he raised her and provided for her education and she resided with him until her marriage in 1975.").

${ }^{300} \mathrm{Id}$.

${ }^{301} \mathrm{Id}$.

${ }^{302} I d$. at 853 ("Because O'Neal's relatives did not have the legal authority to enter into a contract for her adoption, their alleged ratification of the adoption contract was of no legal effect."). 
fairness and intent rather than the ordinary rules of contract law." 303 Consider, for instance, the 2013 case of DeHart v. DeHart in which the Supreme Court of Illinois was confronted with an individual who was disinherited by the man he had always believed to be his father. ${ }^{304}$ The plaintiff, James Dehart, was born in $1944 .{ }^{305}$ For almost sixty years, the decedent, Donald DeHart, had represented himself to the community as James' biological father. ${ }^{306}$ In addition, Donald even provided James with a birth certificate that seemingly confirmed his parentage. ${ }^{307}$ In 2000 , however, James obtained a certified copy of his birth certificate, and it made clear that his father was someone other than Donald. ${ }^{308}$

Donald subsequently conceded that he was not James' biological father, but that he had nonetheless adopted James in $1946 .{ }^{309}$ Consistent with that representation, Donald continued to hold James out as his son. ${ }^{310}$ When Donald subsequently died in 2007, however, his will included the statement that "I have no children" and, indeed, it appeared that he had lied about having adopted James. ${ }^{311}$ In that will, Donald left nothing to James but instead left everything to a woman Donald had wed just two years prior to his death. ${ }^{312}$ James filed a challenge to the will, arguing in part that had been equitably adopted by Donald. ${ }^{313}$ Although Donald's widow disputed the claim, the court ruled in James" favor, holding that "where there is sufficient, objective evidence of an intent to adopt (or fraudulently or mistakenly holding out as a natural child on a continual basis), supported by a close enduring familial relationship, . . equitable adoption [will] be recognized." 314

In so ruling, Illinois joined other states that have permitted equitable adoption claims even in the absence of a formal adoption contract. West Virginia was seemingly the first state to do so when its highest court stated that " $[\mathrm{w}]$ hile the existence of an express contract of adoption is very convincing evidence, an implied contract of adoption is an unnecessary

${ }^{303}$ DeHart v. DeHart, 986 N.E.2d 85, 103 (Ill. 2013).

${ }^{304} \mathrm{Id}$.

${ }^{305} \mathrm{Id}$. at 90 .

${ }^{306}$ Id.

${ }^{307} \mathrm{Id}$. ("Donald and plaintiff used the purported birth certificate, to conduct the affairs of life (until the year 2000), using it to enroll plaintiff in grade school and high school and using it to convey to those requesting proof of identity that plaintiff was Donald's son.").

${ }^{308} \mathrm{Id}$.

309 Id. ("Donald also explained in no uncertain terms that he had hired a lawyer in Homewood, Illinois, to handle the adoption so that 'it was all legal."').

${ }^{310} \mathrm{Id}$.

${ }^{311} I d$. ("There is no legal documentation of an adoption in the record.").

312 Id. at 91 .

${ }^{313} I d$.

${ }^{314} I d$. at 104 . 
fiction created by courts as a protection from fraudulent claims." 315 Accordingly, the court held that an equitable adoption could take place even without a contract to adopt so long as the proponent "can, by clear, cogent and convincing evidence, prove sufficient facts to convince the trier of fact that his status is identical to that of a formally adopted child, except only for the absence of a formal order of adoption." 316 California followed a similar approach in 2004 when its highest court held that one who claims to be an equitably adopted child need only "demonstrate the existence of some direct expression, on the decedent's part, of an intent to adopt the claimant." 317 The court explained that such intent could be established by the existence of "an unperformed express agreement or promise to adopt" ${ }^{318}$ but can also arise from "an invalid or unconsummated attempt to adopt, the decedent's statement of his or her intent to adopt the child, or the decedent's representation to the claimant or to the community at large that the claimant was the decedent's natural or legally adopted child." 319

\section{E. No Adoption and No Biological Link}

Somewhat related to equitable adoption is the concept of equitable parent, which different courts have referred to as quasi-parent, in loco parentis, and psychological parent. ${ }^{320}$ Essentially, an equitable parent is one who gains some parental rights as a result of having acted as a parent to a legally unrelated child, ${ }^{321}$ typically with the consent of the legal parent. ${ }^{322}$ In a growing number of cases, including Ramey $v$. Sutton that was discussed earlier, ${ }^{323}$ same-sex partners have relied on claims of equitable parenthood to gain parental rights over children with whom they lack a biological tie. After all, medical science currently does not permit two people of the same gender to conceive, ${ }^{324}$ meaning that children of same-sex couples will only have-

${ }^{315}$ Wheeling Dollar Sav. \& Trust Co. v. Singer, 250 S.E.2d 369, 374 (W. Va. 1978)

${ }^{316} \mathrm{Id}$.

${ }^{317}$ Estate of Ford, 82 P.3d 747, 754 (Cal. 2004).

${ }^{318} I d$.

${ }^{319} \mathrm{Id}$

${ }^{320}$ See Higdon, supra note 186, at 944.

${ }^{321}$ See Jennifer S. Hendricks, Essentially A Mother, 13 WM. \& MARY J. WOMEN \& L. 429,458 (2007) (defining a quasi-parent as "a person not a legal parent who nonetheless has greater rights in a contest with the legal parent than does any other third party").

322 See, e.g., In re Custody of H.S.H.-K., 533 N.W.2d 419, 435 (Wis. 1995) (adopting a four-part test " $[t] \mathrm{o}$ demonstrate the existence of the petitioner's parent-like relationship with the child" the first element of which is the "that the biological or adoptive parent consented to, and fostered, the petitioner's formation and establishment of a parent-like relationship with the child"); see also supra note 136 and accompanying text.

${ }^{323}$ See supra notes 127-136 and accompanying text.

${ }^{324}$ As advances in assisted reproduction continue, even this may change. See Michael 
at most-a biological connection with one member of the same-sex relationship.

Those in same-sex relationships, of course, are not the first to bring such claims. Individuals who have acted as quasi-parents have a long history of petitioning the courts for parental rights. Although they have not always been successful, the point remains that this is yet one more area of family law where the courts have been willing to bestow familial rights on those who lack formal family relationships. Before looking at those cases, however, it is important to understand that this is an area of the law that is rapidly evolving, due in large part to the fact that family complexity has changed drastically in the last few decades as a result of "higher rates of divorce, nonmarital childbearing, cohabitation, and remarriage." 325 As a consequence of those new dynamics, children today are more likely to look to individuals as parents who are, in reality, "legal strangers." 326 Thus, courts are being asked to increasingly wrestle with the difficult question of, in the absence of a biological or legal connection to the child, can an individual can ever become a "parent." And, if so, how is a court to reconcile that recognition with the parental rights of the child's legal parents.

In several cases, including claims brought by cohabitants, courts have seemed resistant to extend such recognition. For instance, Donald Merkel cohabitated with his girlfriend, Tamera Cooper, and her son for seven years. $^{327}$ Despite being neither the child's legal nor the biological father, Donald nonetheless assumed responsibility for helping raise the boy. ${ }^{328}$ When the relationship between the two adults ended, the Supreme Court of South Dakota refused to recognize him as an equitable parent: "Before a parent's right to custody over his or her own children will be disturbed in favor of a nonparent, a clear showing against the parent of 'gross misconduct or unfitness, or of other extraordinary circumstances affecting the welfare of the child' is required." 329 Step-parents have faced similar difficulties. For example, in a 2009 case out of Illinois, Nicholas Gansner and Miki Mancine

Boucai, Is Assisted Procreation an LGBT Right?, 2016 WIS. L. REV. 1065, 1093 (2016) (discussing technologies whereby sperm cells might be converted to egg cells and vice versa, permitting same-sex couples to reproduce).

325 Ariel Kalil et. al., Time Investments in Children Across Family Structures, 654 AnNAls AM. ACAD. Pol. \& Soc. SCI. 150 (2014)

326 The term "legal stranger" is often used as a synonym for "nonparent." See John Dewitt Gregory, Blood Ties: A Rationale for Child Visitation by Legal Strangers, 55 WASH. \& LEE L. REV. 351 (1998) (using "nonparent" and "legal stranger" interchangeably); David D. Meyer, What Constitutional Law Can Learn from the Ali Principles of Family Dissolution, 2001 B.Y.U. L. REV. 1075, 1087 (2001) (noting that "long-time caregivers lacking biological or adoptive ties are classified as nonparents, or legal 'strangers"').

${ }^{327}$ Cooper v. Merkel, 470 N.W.2d 253 (S.D.1991).

${ }^{328} I d$. at 254.

${ }^{329} I d$. at 255 (quoting Langerman v. Langerman, 336 N.W.2d 669, 670 (S.D.1983)). 
were married a few months after Miki adopted a son, William. ${ }^{330}$ Nicholas never adopted William but nonetheless held himself out as William's father and served as the child's primary caregiver. ${ }^{331}$ When Miki filed for divorce, Nicholas petitioned for sole custody. ${ }^{332}$ The court, however, rejected his argument, noting that the state had not recognized equitable parentage and that Nicholas, despite knowing "at all times that he would have to formally adopt William in order to be his legal parent," failed to do so. ${ }^{333}$

Other courts have been more sympathetic to such claims. For instance, in a 1992 case a Minnesota court granted visitation to a stepfather, David Simmons, over the objections of the child's mother, JoEllen Vasicheck. ${ }^{334}$ The couple had married in 1989. ${ }^{335}$ At the time, JoEllen had a 5-year old son from a previous relationship. ${ }^{336}$ When the couple separated 18 months later, David petitioned the court for visitation. ${ }^{337}$ While acknowledging that "the question of whether a former stepparent may assert a common-law right to visitation is one of first impression," the court ruled in his favor. ${ }^{338}$ Specifically, the court held that "a former stepparent who was in loco parentis with the former stepchild may be entitled to visitation under the common law." 339 Finding nothing in the record to contradict the trial court's determination that visitation with David would be in the child's best interest, the court affirmed. ${ }^{340}$ A number of courts have offered similar relief to those who fail to qualify as legal parents. ${ }^{341}$

Included within those cases are instances where courts have used equitable parentage to bestow parental rights on those in same-sex relationships. For instance, a North Carolina court, applying the best interest of the child standard, awarded joint legal and physical custody of a child to the mother, Irene Dwinnell, and the mother's former partner, Joellen

${ }^{330}$ In re Marriage of Mancine and Gansner, 9 N.E. 3d 550, 555 (Ill. App. Ct. 2014).

${ }^{331} I d$. at 556.

${ }^{332} I d$.

${ }^{333} I d$. at 568 .

334 Simmons v. Simmons, 486 N.W.2d 788 (Minn. Ct. App. 1992).

${ }^{335} \mathrm{Id}$. at 789.

${ }^{336}$ Id. ("[The] biological father has had no contact with him and has surrendered his parental rights.").

${ }^{337}$ Id. at 790.

${ }^{338}$ Id. 791.

339 Id. According to the court, "[b]ecause [the statute] does not contain any clause specifically repealing, restricting, or abridging a non-parent's common-law visitation rights, we construe the statute to extend and supplement the common-law rule."

${ }^{340} \mathrm{Id}$. at 792.

${ }^{341}$ At least one court has relied on equitable adoption to extend parental rights to a samesex spouse. See Stankevich v. Milliron, 882 N.W.2d 194, 197 (Mich. Ct. App. 2015) (ruling that a same-sex spouse could qualify as an "equitable parent" to the biological child of the other spouse when that child was born during the marriage). 
Mason. ${ }^{342}$ Although the mother argued that the ruling would infringe her constitutional rights to direct the upbringing of her child, the court announced that "when a legal parent invites a third party into a child's life, and that invitation alters a child's life by essentially providing him with another parent, the legal parent's rights to unilaterally sever that relationship are necessarily reduced." 343 In so ruling, the court noted that the two women "lived together as a family and Dwinnell led her child to believe that Mason was one of his parents." 344

These cases illustrate but a few of the evolving family forms that have led to increasing numbers of children being reared (sometimes exclusively) by those who fail to qualify as a formal, legal parent. These cases likewise reveal the degree to which the protections afforded equitable parents vary by state. In light of the harms that can befall children when those they see as parents are not treated as such by the law, a number of scholars have argued that state law needs to be more consistent when it comes to recognizing equitable parenthood and in providing those individuals with parental rights. ${ }^{345}$ The same is true regarding backdating claims by those who are unable to count the pre-equality portion of a same-sex relationship toward formal marriage given the unconstitutional laws prohibiting such unions. Just as the states have found ways to award family-like benefits to other relationships that fail to meet the formal requirements of family law, so to must they find ways to extend marital benefits to those who were in relationships that would have been marital had that been a legal option. Although the states need not do so in the same precise way, it is the position of this Article that Obergefell demands some form of equitable remedy - one that currently does not exist in the law but for which the above equitable remedies are highly instructive.

\section{EQUITABLE MARRIAGE}

As detailed above, courts already possess a number of equitable doctrines that enable them to extend family law protections to those who have spent time in informal family-like relationships. ${ }^{346}$ Each owes its existence to the courts' desire to protect vulnerable citizens from the harms that can arise from misplaced reliance on the existence of a formal domestic relationship. Consider, for instance, someone who spends twenty years in a relationship

\footnotetext{
342 Mason v. Dwinnell, 660 S.E.2d 58 (N.C. Ct. App. 2008).

${ }^{343} I d$. at 69.

${ }^{344} I d$. at 68.

345 See generally Higdon, supra note 186, at 956 ("Although state variation is not an inherently bad thing, discrimination on the basis of family structure and the ensuing harm such discrimination plays in the lives of children is something the law cannot tolerate").

${ }^{346}$ See supra Part III.
} 
that she believes to be a marriage. Imagine that she does not work outside the home, and all valuable property is in her spouse's name. If it were somehow revealed that the marriage was invalid, she would - absent some other remedy - be left financially with very little to show for those twenty years and have limited ability to now rebuild her life. It is primarily within this space that these equitable doctrines operate. ${ }^{347}$ There is, however, another concern at play and that is the goal of fulfilling party expectations. ${ }^{348}$ As many courts have referenced when applying these doctrines, these individuals entered into these relationships in good faith, assuming that they would be protected or, at the very least, not jeopardizing their economic self-interests in the process.

Those concerns apply with equal force in the context of those who spent time in same-sex relationships that would have been marriages but for the unconstitutional laws preventing such unions. In truth, those individuals are even more entitled to some sort of protection given the constitutional right at play. As a number of scholars have made clear, this retroactive application of Obergefell is not merely good policy, it is constitutionally required. For instance, Lee-Ford Tritt has concluded that "Obergefell should be applied purely retroactively as to both choice-of-law matters and remedial considerations [so as to] rectif[y] the property deprivations of unconstitutional unrecognized marriages." 349 Similarly, Peter Nicolas explains that "[s]uch backdating provides same-sex couples with the "make whole' relief they are entitled to for past violations of their constitutional right to marry." ${ }^{350}$ Such sentiments are consistent with what the Supreme Court itself has said regarding remedial decrees: "it must be designed as nearly as possible to restore the victims of discriminatory conduct to the position they would have occupied in the absence of such conduct."351

347 See, e.g., supra notes $258 \& 281$ and accompanying text.

348 See, e.g., Ceja v. Rudolph \& Sletten, Inc., 302 P.3d 211, 216 (Cal. 2013) (“Our court made clear from the beginning that the fundamental purpose of the putative spouse doctrine was to protect the expectations of innocent parties and to achieve results that are equitable, fair, and just.”); W. States Const., Inc. v. Michoff, 840 P.2d 1220, 1224 (Nev. 1992) (“[T]his court must protect the reasonable expectations of unmarried cohabitants with respect to transactions concerning their property rights."); Sol Lovas, When Is A Family Not A Family? Inheritance and the Taxation of Inheritance Within the Non-Traditional Family, 24 IDAHO L. REV. 353, 371 (1988) ("[C]ourts have developed the doctrines of 'equitable adoption' and 'adoption by estoppel' to protect the child's justifiable expectations.”); Kathryn S. Vaughn, The Recent Changes to the Texas Informal Marriage Statute: Limitation or Abolition of Common-Law Marriage?, 28 Hous. L. REV. 1131, 1140 (1991) ("The first, and probably most important, function of common-law marriage is protecting the good faith expectations of the parties.").

349 Tritt, supra note 17 , at 945.

${ }^{350}$ Nicolas, supra note 17 , at 441.

${ }^{351}$ Milliken v. Bradley, 433 U.S. 267, 280 (1977) (quoting Milliken v. Bradley, 418 U.S. 
Thus, if those individuals are to be provided with true marriage equality, some retroactivity is required. Unfortunately, none of the existing doctrines are currently suited to address this particular situation. As a result, these individuals require a new form of protection given that their relationships either ended before marriage equality became the law of the land or their eventual marriages fail to capture the true length of the relationship, upon which a number of marital benefits are conditioned. ${ }^{352}$ The remainder of this Part explores why, despite being inapposite in this context, the existing doctrines are nonetheless instructive when it comes to crafting a new equitable doctrine - referred to here as Equitable Marriage - that would offer the necessary protections. With that in mind, this Part then puts forth concrete suggestions on how Equitable Marriage should be applied and how courts should deal with the potential criticisms and complications that could arise.

\section{A. Filling the Equitable Void}

To deal with same-sex relationships that pre-dated marriage equality, one might ask why not simply bring back some form of common law marriage. It is, after all, the only equitable doctrine of the five that gives formal recognition, with all the attendant rights and obligations, to an informally created relationship. ${ }^{353}$ In contrast, the others merely provide for limited rights and remedies. Additionally, there is some precedence for using common law marriage in this context. After Loving, courts took that approach to retroactively extend marriage equality to interracial relationships that were either already in existence ${ }^{354}$ or had ended before Loving. ${ }^{355}$ Further, as discussed earlier, a few states have already relied on common law marriage to retroactively convert some same-sex relationships into marriages. ${ }^{356}$

Nonetheless, there are a number of problems with relying on common law marriage in this context. First, compared to the legal landscape at the time Loving was decided, today only a small number of states permit common law marriage, and that number continues to dwindle. ${ }^{357}$ In 2019, for instance, the Supreme Court of South Carolina prospectively abolished the doctrine after finding that it violated the public policy of the state, which "is to promote predictable, just outcomes for all parties involved in these disputes, as well

717, 746 (1974)).

352 See supra Part II.A.

${ }^{353}$ See supra notes 189-190 and accompanying text.

${ }^{354}$ See Nicolas, supra note 17, at 424-25.

${ }^{355}$ See, e.g., Prudential Ins. Co. of Am. v. Lewis, 306 F. Supp. 1177 (N.D. Ala. 1969) (recognizing a common law marriage between interracial couple even though husband died a few months before Loving was issued).

${ }^{356}$ See supra notes $172-178$ and accompanying text.

${ }^{357}$ See supra note 212 and accompanying text. 
as to emphasize the sanctity of marital union."358 Additionally, most states abolished common law marriage through legislation, ${ }^{359}$ and thus resurrecting the doctrine at this point could take considerable time and pose significant political challenges.

Of greater salience, however, is the fact that the traditional tests for common law marriage are largely based on outdated, heteronormative views of what a marriage should look like. For instance, many states require that parties prove that they cohabitated and had a reputation in the community as being married in order to establish an informal marriage. ${ }^{360}$ However, relationships today-even formal marriages - are less likely to satisfy those elements. Married couples are more likely today to live separately, ${ }^{361}$ and with the reduced societal stigma concerning romantic relationships outside of marriage, they are less likely to proclaim to those around them that they are, in fact, married. ${ }^{362}$ This is especially true when considering same-sex couples who may have feared discrimination and scorn had they openly shared their relationship status with others. In that sense, cases dealing with common law marriage claims involving interracial couples are instructive. For instance, in 1904, the Supreme Court of Missouri refused to recognize a common law marriage between a couple that lived together for thirty years, had eight children, and referred to one another as husband and wife. ${ }^{363}$ The problem was that the two failed the reputation requirement because "he was never known to be with her and acknowledge her as his wife outside of his own house." 364 The reason he had not done so was clearly because he was White and she was Black, but the court gave no weight to that fact. ${ }^{365}$

358 See Stone v. Thompson, 833 S.E.2d 266 (S.C. 2019). The court would, however, continue to recognize common law marriages effectuated prior to that date. $I d$. at 267 (" $[\mathrm{F}] \mathrm{rom}$ this date forward - that is, purely prospectively-parties may no longer enter into a valid marriage in South Carolina without a license.").

${ }^{359}$ See Grace Ganz Blumberg, Legal Recognition of Same-Sex Conjugal Relationships: The 2003 California Domestic Partner Rights and Responsibilities Act in Comparative Civil Rights and Family Law Perspective, 51 UCLA L. REV. 1555, 1577 (2004) (“[D]uring the past two centuries, common law marriage has been legislatively abolished in most states.").

360 See supra note 216 and accompanying text.

361 See Simon Duncan, Why More Couples Are Choosing to Live Apart, THE CONVERSATION (Jan. 3, 2020) ("Not only is it surprisingly common, but living apart together is increasingly seen as a new and better way for modern couples to live."): https://theconversation.com/why-more-couples-are-choosing-to-live-apart-124532

362 Stone, 833 S.E.2d 269 ("By and large, society no longer conditions acceptance upon marital status or legitimacy of children.”).

${ }^{363}$ Keen v. Keen, 83 S.W. 526 (Mo. 1904).

${ }^{364} \mathrm{Id}$. at 527.

365 See also Vetrano v. Gardner, 290 F. Supp. 200, 206 (N.D. Miss. 1968) (refusing to find a common law marriage even though it was "suggested that the parties would have conducted themselves publicly as husband and wife but for their fear of prosecution under state criminal statutes banning interracial marriage"). 
There is one final reason that common law marriage does not work particularly well in the context of same-sex relationships that pre-date marriage equality, and it is a problem also shared by the marriage validation principles of marriage by estoppel and putative marriage. Namely, all three operate on the assumption that there was in fact a marriage, albeit one that is invalid or was entered into informally. Indeed, the essential requirement for common law marriage is a shared intent of the parties to be legally married. ${ }^{366}$ Thus, common law marriage requires, not that the parties subjectively believed their relationship to be the equivalent of a marriage, but that they intended to enter into a relationship that they believed would be recognized as a legal marriage. ${ }^{367}$ In fact, states that allow common law marriage require the parties to have first had the capacity to marry, meaning that they could have obtained a formal marriage had they so chose. ${ }^{368}$ However, at the heart of the marriage equality movement lies the fact that same-sex couples were denied that capacity. Thus, for those who entered into same-sex relationships before gaining the right to legally wed, they may have considered themselves the equivalent of married, but they were always well aware that it was an extralegal relationship that came with no marital benefits or protections. ${ }^{369}$

Likewise, marriage by estoppel assumes that, although there may have been an invalid divorce, there was a subsequent marriage ceremony that was otherwise valid. ${ }^{370}$ Thus, that doctrine has limited utility here because, besides the fact it only operates in a very specific factual setting, a subsequent marriage was something same-sex couples simply could not obtain prior to marriage equality. Similarly, putative spouse doctrine requires a showing that there was a marriage ceremony, and the parties entered into that "marriage" in good faith. ${ }^{371}$ Again, prior to earning the right to marry, same-sex couples could not meet that requirement. It is true that the law could retroactively treat - as some states have done through legislation ${ }^{372}$ - civil unions and domestic partnerships as marriages, but that too fails because 1) relatively few states even offered those marriage alternatives ${ }^{373}$ and 2) like marriage

366 See supra notes 214 and accompanying text.

367 See Morrow v. Dillard, 257 So. 3d 316, 324 (Ala. Civ. App. 2017) (“'In order ‘[t]o establish a common-law marriage, there must be a present agreement or mutual understanding to enter into the marriage relationship."').

368 See supra note 217 and accompanying text.

${ }^{369}$ See, e.g., Swicegood v. Thompson, No. 2018-000008, 2020 WL 3551786, at*1 (S.C. Ct. App. July 1, 2020) ("Thompson attested Swicegood knew they were not married. She stated she and Swicegood participated in a 'commitment ceremony' ... but they knew it was not a wedding and that they could not legally marry.").

${ }^{370}$ See supra notes 238-252 and accompanying text.

${ }^{371}$ See supra notes 253-265 and accompanying text.

372 See supra notes 161-162 and accompanying text.

373 See, e.g., Mitchell L. Engler, Edward D. Stein, Not Too Separate or Unequal: Marriage Penalty Relief After Obergefell, 91 WASH. L. REV. 1073, 1088 (2016) ("By 2012, 
equality itself, those options did not become available until after many samesex couples had already spent years in a committed relationship. ${ }^{374}$ Finally, a putative spouse is not entitled to the full panoply of marital benefits, thus making it a less than ideal template in this context. ${ }^{375}$

For that reason, the law of cohabitation may appear a better alternative, but it too fails in this context. First, that doctrine and its attendant remedies are directed solely at nonmarriage, and in order to achieve true marriage equality, there needs to be some mechanism for treating an informal relationship as an actual marriage. Second, most states that permit cohabitants to avail themselves to marriage-like protections do so through contract lawoften requiring express, written agreements. ${ }^{376}$ The contract requirement is problematic here because, even if one could succeed on that theory, the remedy is limited to the terms of the contract and not the full range of marriage benefits. Further, it is unlikely that same-sex couples who were in committed relationships awaiting the right to legally marry would have even thought of their relationships as a contract, much less in express terms that they then reduced to writing. There is, however, at least one state that does not require an agreement, but instead looks to the quality of the relationship. ${ }^{377}$ Nonetheless, it still only provides successful litigants with some of the benefits of marriage. It does not permit a finding that the couple was in fact married, thus denying them the full "constellation of benefits" to which Obergefell spoke. ${ }^{378}$

What remains, then, are the equitable doctrines relating to parent-child relationships. Although neither pertains to marriage, they nonetheless provide helpful examples of how courts have constructed remedies that allow courts to extend family law protections to those who fail - at least formallyto qualify as "family." As an initial matter, they both share the same defects as some of the other doctrines, the most notable of which is the limited remedies they provide. For instance, succeeding as an equitable parent merely

... nine states allowed same-sex civil unions or domestic partnerships.").

${ }^{374}$ California was the first to pass a domestic partnership registry in 1999, and Vermont was the first to pass legislation permitting civil unions in 2000. See David B. Oppenheimer et. al., Religiosity and Same-Sex Marriage in the United States and Europe, 32 BERKELEY J. INT'L L. 195, 197 (2014).

${ }^{375}$ See, e.g., Allen v. W. Conference of Teamsters Pension Tr. Fund, 788 F.2d 648, 650 (9th Cir. 1986) ("Marriage is a status precisely defined in California and does not cover putative spouses."); Williams v. Williams, 97 P.3d 1124, 1131 (Nev. 2004) (declining "to extend the[putative spouse] doctrine to permit an award of spousal support"); Helen Chang, California Putative Spouses: The Innocent, the Guilty, and the Law, 44 Sw. L. REV. 327, 328 (2014) ("Only certain benefits and privileges of a legal marriage are available to putative spouses.").

${ }^{376}$ See supra notes $274-277$ and accompanying text.

${ }^{377}$ See supra notes 282-288 and accompanying text.

${ }^{378}$ Obergefell v. Hodges, 135 S. Ct. 2584, 2590 (2015). 
provides the possibility of some discrete parental rights - it does not recognize the equitable parent as a legal parent. ${ }^{379}$ Likewise, establishing that one has been equitably adopted only provides limited remedies vis-à-vis the rights afforded formally adopted children. ${ }^{380}$ Further, as detailed earlier, most states are fairly formalistic when it comes to applying these doctrines. In equitable adoption, for example, most courts insist on the existence of an unfulfilled adoption contract, which may be unusual in situations where informal adoption is likely to occur. ${ }^{381}$ Relatedly, equitable parentage cases often focus too much on the role the legal parent played in cultivating the relationship between the child and the quasi-parent and not enough on the quality of the relationship that developed between the two or the harm that would result from failing to protect that relationship. ${ }^{382}$

Nonetheless, a survey of the states that have applied these doctrines reveal that a few have instead adopted a more nuanced approach, one that is similar to how Washington deals with unmarried partners. ${ }^{383}$ Specifically, these courts have utilized a functional approach, which "focuses the inquiry on whether the relationship at issue shares the essential characteristics of a traditionally accepted relationship and fulfills the same human needs." 384 Although such an approach might appear to be the minority approach regarding these doctrines, family law as a whole has increasingly moved in the functional direction. ${ }^{385}$ It is the position of this Article that a similar approach would be well-suited in this context as well, providing courts with the necessary flexibility to examine same-sex relationships that pre-dated marriage equality.

Thus, what courts need is a new doctrine, referred to here as Equitable

379 See, e.g., In re P.L., 37 Cal. Rptr. 3d 6, 8-9 (Cal. App. 2005) ("De facto parents have limited rights [and] that status does not give them the rights accorded to a parent or legal guardian.").

${ }^{380}$ See, e.g., Danaya C. Wright, Inheritance Equity: Reforming the Inheritance Penalties Facing Children in Nontraditional Families, 25 CORNELL J.L. \& PUB. POL'Y 1, 46-47 (2015) ("The doctrine provides limited remedies when a functional parent $* 47$ dies intestate, but virtually no remedy for the plethora of ancillary rights dependent upon the legal status of being a parent or a child.").

381 See supra notes 294-295 and accompanying text.

382 Although some states are willing to consider harm, the harm has to be fairly severe before the court will act on that basis. See, e.g., Roth v. Weston, 789 A.2d 431, 445 (Conn. 2002) (holding that a quasi-parent can only justify state interference with the rights of the child's legal parent(s) if the quasi-parent can prove that the child will otherwise "suffer real and substantial emotional harm").

383 See supra notes 282-288 and accompanying text.

384 Brad Sears, Winning Arguments/losing Themselves: The (Dys)functional Approach in Thomas S. v. Robin Y., 29 HARV. C.R.-C.L. L. REV. 559, 566 (1994).

385 See Kate Redburn, Zoned Out: How Zoning Law Undermines Family Law's Functional Turn, 128 YALE L.J. 2412, 2422 (2019) ("In many states, parentage and partnership doctrines have taken a 'functional turn' over the past forty years.”). 
Marriage, which would draw upon elements of the existing approaches to recognizing informal relationships. At a minimum, this doctrine would need to give the courts license to extend benefits to a marriage-like relationship that cannot otherwise qualify as a legal marriage. In that sense, this new doctrine would be similar to the marriage validation principles of marriage by estoppel and putative marriage, which protect void marriages, and equitable parentage and adoption, which protect informal parent-child relationships. However, unlike those doctrines, this new equitable doctrine needs to provide not just some family law protections, but all of the rights and obligations associated with marriage. In that sense, its remedy would be akin to that of common law marriage, which confers all the benefits associated with formal marriage. At the same time, however, the approach that is needed in this context cannot share common law marriage's rigid, outdated definition of marriage. Nor, like typical cohabitation law and equitable adoption, can it blindly insist on the existence of a contractual relationship. Instead, it should take a more functional approach, similar to that taken by a minority of courts regarding cohabitation, equitable adoption, and equitable parentage. Finally, given the fundamental right at issue, this doctrine requires nationwide application (in whatever precise form each state decides) in order to remedy the constitutional harms that stem from the states' history of refusing to permit same-sex marriage.

\section{B. Applying Equitable Marriage}

At its most basic level, Equitable Marriage would allow an individual who spent time in a same-sex relationship prior to the legalization of samesex marriage to argue that some portion of that relationship should be considered either the equivalent of a legal marriage or, in the case of a couple that ultimately did wed, as part of that eventual marriage. In order to prevail, a claimant would have to demonstrate that the parties would have wed during that period if the law had permitted them to do so. Finally, for those who succeed, the court would then rule that there was a legal marriage during that period of the relationship - a remedy that, like common law marriage, brings with it all the "same terms and conditions" as formal marriage. ${ }^{386}$

Given the large number of LGBTQ Americans living today who were in same-sex relationships impacted by the denial of marriage equality, it is likely that individuals from that group will be asking courts for such relief for years to come. As courts grapple with how to respond to such claims, Equitable Marriage offers a way of not only addressing them, but doing so in a way that fulfills Obergefell's promise of true marriage equality. Still, as courts

${ }^{386}$ Obergefell v. Hodges, 135 S. Ct. 2584, 2593 (2015). 
implement such a doctrine, a number of questions are likely to arisequestions the remainder of this section identifies and attempts to address.

\section{Who Has Standing?}

As an initial matter, the question arises as to who would be permitted to raise an Equitable Marriage claim and whether there would be any time limits for doing so. There are two groups of people who could conceivably raise such claims. First are those individuals who ultimately wed a same-sex partner with whom they had enjoyed a nonmarital relationship prior to obtaining the right to legally wed. ${ }^{387}$ The second group includes those who were in a nonmarital relationship that ended, either through divorce or dissolution, prior to the arrival of formal marriage equality. Individuals in either category would have the potential to raise a claim of Equitable Marriage.

It would only be a potential claim given that some states may opt to impose some time limits, and there are two such restrictions that could come into play. First, for those who ultimately did wed and are seeking to backdate their wedding date to an earlier point in time, there is the question of how soon after obtaining the right to marry did the couple wed. For instance, claimants would certainly be more sympathetic if they were part of a couple that requested and received a marriage license the very day their state started issuing marriage licenses. For those who did not immediately wed, however, the issue gets a bit more complicated. Planning a wedding can certainly take time, but imagine a couple that waited five years after their state started issuing licenses before finally entering into a formal marriage. Given that marital backdating would remain somewhat of an extraordinary remedy, the states may feel it only fair to reserve that remedy to those who promptly did all they could to formalize their relationship once given the ability to do so. Thus, it may well be that states are correct in refusing claims for equitable marriage by those who waited too long to marry after receiving the right to do so.

States must be mindful, however, of not unfairly punishing those who do not immediately wed. For a historical example of states doing just that, consider how the southern states, following passage of the Thirteenth Amendment, forced former slaves to either promptly wed or face criminal conviction. Specifically, "[t]hose who were already in cohabitating relationships were told to immediately legalize their unions and legitimize

${ }^{387}$ Because different states recognized that right at different points in time, see supra Part I, it is the assumption of this Article that Equitable Marriage would consider when marriage equality became available in the state the same-sex couple resided. 
their children and grandchildren." 388 At least one southern state gave the former slaves just six months to do so or be subject "to criminal prosecution for adultery and fornication." 389 Thus, as Katherine Franke has discussed, "the robust enforcement of bigamy, fornication, and adultery laws served to domesticate African American people who were either unaware of, or ignored, the formal requirements of marital formation and dissolution." 390

In requiring that same-sex couples promptly marry in order to evidence an intention to wed earlier than they had been legally permitted to do so, states must be mindful that imposing too short of a deadline would continue to promote the very discrimination Obergefell was aimed at ending. There is, unfortunately, one case where that has already occurred. In Ferry v. De Longhi America, Inc., a case arising out of California, Patrick Ferry and Randy Sapp started living together in 1985. ${ }^{391}$ In 1993, they "were married in a religious ceremony performed by a religious leader pursuant to the principles of [their] beliefs." 392 The two men lived together until December of 2013, when Randy tragically died as a result of a heater that allegedly malfunctioned. ${ }^{393}$ When Patrick brought a wrongful death action, the manufacturer moved to dismiss on the basis that Patrick was not Randy's legal spouse and, thus, lacked standing. ${ }^{394}$ The court agreed, noting that same-sex marriage became legal in California in June 2013 and, thus, the two men could have legally wed prior to Randy's death if they had so intended. ${ }^{395}$ In essence, then, the two men had lived as a married couple for over thirty years but were punished for not obtaining a marriage license in the six months between finally gaining the right to do so and Randy's death.

A second potential time restriction relates to when someone could bring a claim for Equitable Marriage. For those who ultimately wed, it would seem they would have to do so at the point in time - most likely death or divorcewhen they are being denied a marriage benefit on the basis of marital length. However, states might do what Utah has done regarding common law marriage and condition backdating on the requirement that the spouses first

${ }^{388}$ HUNTER, supra note 2, at 236.

${ }^{389}$ Katherine M. Franke, The Domesticated Liberty of Lawrence v. Texas, 104 CoLuM. L. REV. 1399, 1421 (2004).

${ }^{390}$ Katherine M. Franke, Becoming A Citizen: Reconstruction Era Regulation of African American Marriages, 11 YALE J.L. \& HUMAN. 251, 257 (1999).

391276 F. Supp. 3d 940, 943 (N.D. Cal. 2017).

392 Id. at 943 . According to Patrick, "Had it been possible to do so [they] would have obtained a marriage license." Id.

${ }^{393} \mathrm{Id}$.

${ }^{394} I d$. at $944-45$.

395 Id. at 949-50. Per the court, "the act of obtaining a marriage license is an administrative burden that all couples must bear if they wish to avail themselves of the legal rights and privileges of a formal marriage." Id. at 952. 
petition the court, either during the relationship or within one year of its termination, for an order setting the start date of their marriage at a point earlier than when they formally wed. ${ }^{396}$ The benefit of such an approach is that it forces individuals in this position to ask for backdating sooner rather than later, when problems of proof may be exacerbated by the passage of time or the death or incapacity of one of the spouses.

The question is more complex though when applied to those whose samesex relationships ended before they were permitted to marry. To illustrate, consider two men who were in a long-term relationship that began in 1995 but ended in 2010 when the couple decided to go their separate ways. One of the men dies in 2021. The other wants to claim that he should receive widower's benefits, and so he brings a claim for equitable marriage in which he argues that the two would have wed prior to 2010 if permitted to do so. There are a few ways states might deal with such issues. First, the court could simply treat it as a marriage that was never legally terminated. That would pose problems if either had subsequently remarried. However, under the subsequent marriage presumption, most states would honor the later marriage, presuming that the earlier one ended in divorce before the subsequent marriage took place, and it would be very hard for the surviving partner to prove otherwise. ${ }^{397}$ If neither had "remarried," then the claimant would be permitted to prove the existence of an Equitable Marriage.

A better solution, however, might be for states to create a statute of limitations that applies to those who wish to have a pre-equality relationship adjudicated as a marriage. Texas, for instance, provides that a claimant's ability to establish a common law marriage will fail "[i]f a proceeding in which a marriage is to be proved . . . is not commenced before the second anniversary of the date on which the parties separated and ceased living together." 398 States could implement something similar regarding Equitable Marriage for those who seek marital benefits from a relationship that ended before the arrival of formal marriage equality. However, the event that would start the clock in this context would likely need to be the date upon which the state began recognizing Equitable Marriage given that many of these relationships might have already ended many years earlier.

\section{How Would a Claimant Prove an Equitable Marriage?}

One might ask, given the deprivations they have faced regarding marriage, why not simply give same-sex couples the benefit of the doubt and

396 See UTAH CODE $§ 30-1-4.5$ (2011).

397 See Higdon, supra note 179, at 117 ("In essence, the subsequent marriage presumption operates by presuming a divorce, when in fact, one likely never occurred.").

${ }^{398}$ See Tex. FAm. CodE AnN. $§ 2.401$ (West) 
automatically presume that any relationship that existed prior to marriage equality was a marriage that is entitled to all the corresponding rights and benefits. There are two responses to that question. First, such a permissive approach could very easily give rise to fraudulent claims, especially considering that such claims might not arise until after the alleged spouse has died. Second, marriage does not simply bring benefits, it also brings obligations. Accordingly, whenever an individual succeeds in backdating a same-sex marriage, that person's spouse then has marital obligationsobligations that person may have never intended to bear. In other words, backdating a same-sex marriage might be very beneficial to one spouse, but it can also be quite damaging to the other. ${ }^{399}$ Thus, more careful consideration is required if the law is to adequately protect both members of the same-sex couple.

Indeed, not every same-sex relationship that came into being prior to formal marriage equality would have been a marriage. To begin with, the decision to marry typically does not arise until after some period of courtship, ${ }^{400}$ which could take as much time as the couple deems necessary. Thus, just because a claimant can prove the existence of a pre-equality relationship, does not mean the parties would have been married at that particular point in time. Further, with the reduced social stigma associated with cohabitation, ${ }^{401}$ a growing number of opposite-sex couples consciously choose not to marry, and those same considerations could have easily influenced same-sex couples to elect to do the same even if they had the option. Additionally, some same-sex couples may have possessed unique reasons for rejecting the idea of marriage, most notable of which is the belief

${ }^{399}$ Relatedly, if one partner dies, retroactively finding a marriage can have significant harms on the deceased partner's heirs if that person died intestate. See, e.g., Irene D. Johnson, There's A Will, but No Way-Whatever Happened to the Doctrine of Testamentary Freedom and What Can (Should) We Do to Restore It?, 4 Est. Plan. \& Community Prop. L.J. 105, 123 (2011) ("Intestate succession statutes send a decedent's property to a spouse and children, or if there is no spouse or children, then to blood relatives.").

${ }^{400}$ One scholar has described marriage as having four distinct stages:

[T] he courtship stage, in which the couple meets and decides to marry; the entry stage, in which the couple undergoes whatever licensing and ceremonial requirements are necessary to achieve marital status; the intact marriage stage, in which the couple is legally married; and the exit stage, in which the couple divorces, has the marriage annulled, or one of the spouses dies.

Kerry Abrams, Immigration Law and the Regulation of Marriage, 91 MINN. L. REV. 1625, 1628 (2007)

401 See Courtney G. Joslin, The Gay Rights Canon and the Right to Nonmarriage, 97 B.U. L. REV. 425, 444 (2017) (noting that, "[t] oday, there is less social stigma associated with living in a nonmarital family"). 
by some in the LGBTQ community that "it puts undue emphasis on a heteronormative institution." 402 As one commentator recently described, "[g]ay marriage is not without controversy, even among LGBT rights activists. Queer theorists, radical feminists, and libertarians like Judith Butler, Martha Fineman, and David Boaz, reject gay marriage and advocate for the abolition of marriage in general." ${ }^{403}$

Thus, for all those reasons, the question arises as to how courts are to, $e x$ post, differentiate between same-sex relationships that would have been marriages and those that would not. Even those that would have been marriages at some point prior to formal marriage equality, the question becomes when did the relationship reach that point. And all of these questions are even made more complicated by the fact that, once the same-sex relationship ends, the two parties may have very different perspectives on what was intended at any one point in time. Failure to get it right could be quite damaging to one or both individuals in the same-sex relationship.

Consider, for instance, In re Estate of Leyton, where a New York court declined to backdate a same-sex marriage when doing so would have harmed the surviving member of that relationship. ${ }^{404}$ There, Mauricio Leyton's mother and sister brought suit to have his former partner, David Hunter, disqualified as a beneficiary under Mauricio's will. ${ }^{405}$ When Mauricio died, his will identified David as his "former romantic partner and long-time friend." ${ }^{406}$ Mauricio's family argued that, under New York law, David was a "former spouse," and thus he should be disqualified as a beneficiary. ${ }^{407}$ The two men were never formally married. They did, however, have a commitment ceremony in 2002 but eventually separated. ${ }^{408}$ As a result, Mauricio's family argued that "because the minister at the commitment ceremony observed that the [Mauricio and David] were entering into a state of companionship that the world recognizes as marriage, they were in fact married, and therefore their subsequent separation was a divorce." 409 The lower court denied the family members' claim on the basis that same-sex marriage was not permitted in New York until 2011. ${ }^{410}$ The appellate court

402 David Luban, The Moral Complexity of Cause Lawyers Within the State, 81 FORDHAM L. REV. 705, 709 (2012).

${ }^{403}$ Jessica Brown, Human Rights, Gay Rights, or Both? International Human Rights Law and Same-Sex Marriage, 28 FlA. J. INT'L L. 217, 221 (2016).

${ }^{404}$ In re Estate of Leyton, 22 N.Y.S.3d 422, 423 (N.Y. App. Div. 2016).

${ }^{405}$ In re Leyton, 2015 WL 3882524, at *1 (N.Y.Sur. June 16, 2015) ("The relief sought would increase petitioners' interests as beneficiaries under the will.”).

${ }^{406} \mathrm{Id}$

${ }^{407}$ Id. (relying on N.Y. Est. POWERS \& TRUSTS LAW § 5-1.2(a)(4) (McKinney 2017)).

${ }^{408} I d$.

${ }^{409} \mathrm{Id}$.

${ }^{410}$ Id. ("Here, petitioners seek to have this court apply the Marriage Equality Act 
affirmed but further noted that Obergefell "does not compel a retroactive declaration" that a marriage existed in this instance, holding that "according the union between decedent and Hunter retroactive legal effect would be inconsistent with their understanding that they had never been legally married." 411

The challenge, then, is "to design clear criteria that separate marriage-like unions from those in which the parties are not married because they do not want marital commitment or obligations." 412 And when it comes to setting that criteria, at least one scholar has advocated for "bright-line markers." 413 Specifically, Allison Tait has proposed that courts look to "instances of clear legal intention to form an economic partnership."414 Tait includes within that category such things as asset-specific events, such as the purchase of a family home; the date upon which the couple entered into an alternative marital state like a civil union or a domestic partnership; and other legal contracts that signal "shared purpose and relationship commitment." 415 It is the position of this Article that these "legal markers" would indeed be excellent indicators for courts to rely upon when deciding whether a same-sex relationship that pre-dated marriage equality would have been marital or was instead intentionally nonmarital.

Courts, however, must be willing to delve deeper. As discussed earlier in the context of cohabitation and equitable adoption, ${ }^{416}$ relying too heavily on legal formalities will discriminate against a number of same-sex couples. For instance, only a small number of states even permitted same-sex couples to enter into civil unions and domestic partnerships. ${ }^{417}$ Thus, those who lived in states without that option would be at a disadvantage if courts were to place undue weight on those marriage alternatives. Further, even those states that did offer that option, did so only relatively recently, ${ }^{418}$ meaning that many individuals in those states had already spent years in a same-sex relationship before they even had the choice of entering into a civil union or domestic partnership.

retroactively to the commitment ceremony, deeming that ceremony as formalizing a marriage and the subsequent separation as a divorce.").

41122 N.Y.S.3d at 423.

412 Elizabeth S. Scott, Marriage, Cohabitation and Collective Responsibility for Dependency, 2004 U. CHI. LEGAL F. 225, 258 (2004).

413 See Allison Anna Tait, Divorce Equality, 90 Wash. L. ReV. 1245, 1303 (2015).

${ }^{414} I d$.

${ }^{415}$ Id. at 1303-06. According to Tait, "[v]ivil unions, registered domestic partnerships, designated beneficiary relationships, and relationship contracts all enable couples to signal a clear legal intent." Id. at 1306.

416 See supra Part III.C. \& D.

417 See note 373 and accompanying text.

418 See note 374 and accompanying text. 
Somewhat relatedly, if courts were to rely too heavily on contractual arrangements between same-sex partners - such as designated beneficiary or cohabitation agreements ${ }^{419}$ — as a proxy for their earlier desire to marry, that would penalize those individuals who were ignorant of such options or who lacked access to the legal representation required to effectuate such agreements. ${ }^{420}$ Relying too heavily on the acquisition of joint property, like a family home, would likewise have a disproportionate impact on those who were in less affluent relationships - ones that could not afford such purchases. In short, relying exclusively on "bright-line" markers would fail to account for various ways in which same-sex couples might have expressed their commitment to one another when formal marriage was not an option.

As a result, it is the position of this Article that courts should look beyond discrete markers and instead adopt a more functional approach. Unlike the more rigid approaches courts have taken regarding cohabitation and equitable adoption, courts should permit claimants to rely on other evidence that the couple would have married had that option been available. For instance, as evidenced by the equitable parentage cases discussed earlier, ${ }^{421}$ the fact that the two parties made the decision to have and jointly raise children should likewise have bearing on the question of Equitable Marriage. States that permit common law marriage already take into account such evidence when deciding whether there was an informal marriage, ${ }^{422}$ and it would thus seem odd to apply a more restrictive test here in light of the remedial nature of a doctrine like Equitable Marriage, especially when such a remedy is likely constitutionally required.

Similarly, the cohabitation and reputation requirements of common law marriage should likewise play some role in Equitable Marriage. Individuals who were in same-sex relationships that involved many years of living together should be able to at least present that evidence and have the court consider it. After all, "in the case of long-term relationships - especially those accompanied by economic dependency and specification of roles-extra-

419 See Tait, supra note 413, at 1306.

${ }^{420}$ Tait acknowledges these limitations. See id. at 1309 ("Using legal markers privileges those individuals who have access to legal representation and can write cohabitation agreements, wills, and other legal documents.").

421 See supra Part III.E.

422 See, e.g., Seabrook v. Simmons, No. 2005-UP-459, 2005 WL 7084298, at *3 (S.C. Ct. App. July 19, 2005) (noting that the preponderance of the evidence supported the conclusion that the parties had effectuated a common law marriage, including the fact that they had two children together); see also Ariela R. Dubler, Wifely Behavior: A Legal History of Acting Married, 100 COLUM. L. REV. 957, 971 (2000) ("[I]n cases involving children, who would be deemed illegitimate if a court found their parents' relationship nonmarital, courts recognizing common law marriages clung to a similar presumption in favor of legitimacy as opposed to illegitimacy. 
contractual considerations like protecting weaker, dependent parties, take on a greater weight." 423 Indeed, as one scholar points out, "long-term cohabitation and joint ownership of property might be the best indicator that two people expect to be able to live out their lives enjoying the jointly-owned property." 424 So too should those who publicly represented themselves as being in a committed relationship - either through general reputation in the community or through informal declarations like a commitment ceremonybe permitted to rely on that evidence to prove that that they would have married had that choice been available.

This is not to say that any of this evidence, by itself, should be dispositive or an earlier intent to wed. After all, the evidence could objectively indicate more than one possible intent, and the parties themselves may not be particularly helpful in sorting that out given that "at the dissolution of a relationship, parties may easily disagree or remember differently what intent existed at what point in time." ${ }^{425}$ Nonetheless, to foreclose claimants from even raising such evidence, and instead allowing only specific events to serve as evidence of marital intent would fail to recognize the nuance that is necessary to achieve true marriage equality in any meaningful way. As Jeffrey Evan Stake observed: "What different people want and expect out of marriage, and divorce, is not the same, probably ought not be the same, and in any case cannot be made the same." 426

That last point has particular salience in this context. Namely, homosexual relationships are not identical to heterosexual relationships. Many of those who spent time in same-sex relationships prior to marriage equality grew up in a society where marriage was not only impossible, but the relationships they were permitted to have were both marginalized and, in many respects, demonized. In light of those societal forces, it is entirely reasonable to assume that those same-sex relationships would look somewhat different from traditional marriages that were occurring around the same time. Thus, as courts go about trying to discern whether a prior same-sex relationship would have been a marriage, they must be careful to not be overly swayed by heterosexist conceptions of what marriage should look like. In that sense, the words of Paula Ettlebrick, which she uttered in 1989 when marriage equality was only a whisper, are particularly instructive: "The

${ }^{423}$ Shahar Lifshitz, Married Against Their Will? Toward A Pluralist Regulation of Spousal Relationships, 66 WASH. \& LEE L. REV. 1565, 1621 (2009)

${ }^{424}$ Patricia A. Cain, DOMA and the Internal Revenue Code, 84 CHI.-KENT L. REV. 481, 516 (2009); see also Ellen Kandoian, Cohabitation, Common Law Marriage, and the Possibility of A Shared Moral Life, 75 GEO. L.J. 1829, 1864 (1987) (describing "long-term cohabitation" as "evidence presumptive of marriage").

${ }^{425}$ Tait, supra note 413 , at 1308 n. 323 ,

${ }^{426}$ Jeffrey Evans Stake, Mandatory Planning for Divorce, 45 VAND. L. REV. 397, 398$99(1992)$ 
moment we argue ... that we should be treated as equals because we are really just like married couples and hold the same values to be true, we undermine the very purpose of our movement and begin the dangerous process of silencing our different voices." 427

Many of these differences were explored earlier when discussing how common law marriage provides a less than ideal remedy in this context. ${ }^{428}$ Specifically, same-sex couples who faced discrimination and hostility over their relationship status may have been less likely to live together as well as announce their relationship status to the larger community. But there is another key difference as well, and that relates to the gender stereotypes often associated with marriage. As courts attempt to look back in time to determine whether a same-sex relationship would have been a marriage, they will be unable to rely on the popular stereotypes of the "working husband" and "homemaker wife." There is a great deal of literature about how so much of family law has been built on those stereotypes, ${ }^{429}$ but one of the most recent examples, which is particularly instructive in this context, is the law of nonmarriage and cohabitation. As Albertina Antognini has pointed out, in looking at cases that wrestle with whether to extend marital benefits to cohabitating couples based on how closely those relationships resemble a marriage, "[t]he overarching definition of marriage that these decisions impose is one steeped in archetypal gender relations." 430 When analyzing relationships involving two men or two women, however, such defaults are even less likely to be effective and, thus, the law must "confront[] the sleeping dog, by challenging the rigidity of gender role and identity that conspires with political will to deny the creative possibility and richness in all lives of committed intimate relation." 431

Thus, just as Obergefell distilled marriage down to the four essential attributes that rendered it a fundamental right, ${ }^{432}$ so too must courts discern what are the hallmarks of marital relationships - after heterosexist notions are stripped away - that would allow an individual in a same-sex relationship to prove an intent to be married during a time when that right was being

427 Paula L. Ettelbrick, Since When is Marriage a Path to Liberation?, in WE ARE EVERYwhere: A Historical SOURCEBOOK In Gay AND LeSBian Politics 757, 758 (Mark Blasius \& Shane Phelan eds., 1997).

${ }^{428}$ See supra notes 349-369 and accompanying text.

${ }^{429}$ Albertina Antognini, The Law of Nonmarriage, 58 B.C. L. REV. 1, 60 (2017).

${ }^{430}$ See, e.g., Susan Frelich Appleton, Presuming Women: Revisiting the Presumption of Legitimacy in the Same-Sex Couples Era, 86 B.U. L. Rev. 227, 291 (2006) (noting that "pernicious gender stereotypes ... arise[] from the patriarchal (and racist) context in which we have traditionally approached marriage, reproduction, and family law more generally").

431 John G. Culhane, Uprooting the Arguments Against Same-Sex Marriage, 20 CARDOZO L. ReV. 1119, 1149 (1999).

${ }^{432}$ See supra notes $89-102$ and accompanying text. 
unconstitutionally denied. Although the above discussion attempts to delineate what form this evidence might take, courts must be mindful of the lens through which they view that evidence. In short, no longer is it permissible to use the pre-Obergefell construction of marriage.

\section{CONCLUSION}

In Obergefell, when discussing the flexible role that history and tradition play in constitutional jurisprudence, the majority noted it "respects our history and learns from it without allowing the past alone to rule the

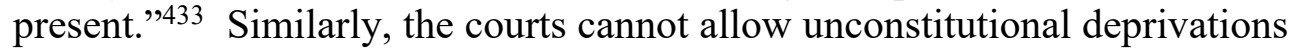
from the past to continue harming people in the present. Thus, as courts wrestle with how to fulfill Obergefell's promise of true marriage equality, they must be mindful of all the individuals who continue to face harm as a result of the states' denial of same-sex marriage through laws that, until 2015, were considered perfectly legal in many states. Although some courts have begun experimenting with ways to backdate marriages and thus ameliorate those harms, states have done so on an inconsistent basis and none have fashioned remedies that adequately capture the unique and varied attributes of same-sex relationships in the United States. Thus, it is the position of this Article that states do more. Specifically, by borrowing and expanding upon the equitable doctrines that already exist for awarding family law benefits to those in informal family-like relationships, the states must develop a doctrine for recognizing Equitable Marriage in order to protect the rights and interests of those individuals who spent time in relationships that would have been marriages had an unconstitutional law not stood firmly in the way. In that respect, the words of Justice Ginsburg in U.S. v. Virginia are instructive: "[a] remedial decree ... must closely fit the constitutional violation; it must be shaped to place persons unconstitutionally denied an opportunity or advantage in the position they would have occupied in the absence of discrimination." $" 434$

${ }^{433}$ Obergefell v. Hodges, 135 S. Ct. 2584, 2598 (2015).

${ }^{434}$ U.S. v. Virginia, 518 U.S. 515, 547 (1996). 